DOE/EW/ $53023-T / 2$

\title{
Tulane/Xavier University Hazardous Materials In Aquatic Environments Of The Mississippi River Basin
}

\author{
Quarterly Progress Report
}

Project \#DE-FG01-93EW53023

(July 1, 1995 - September 30, 1995)

\section{DISCLAIMER}

This report was prepared as an account of work sponsored by an agency of the United States Government. Neither the United States Government nor any agency thereof, nor any of their employees, makes any warranty, express or implied, or assumes any legal liability or responsibility for the accuracy, completeness, or usefulness of any information, apparatus, product, or process disclosed, or represents that its use would not infringe privately owned rights. Reference herein to any specific commercial product, process, or service by trade name, trademark, manufacturer, or otherwise does not necessarily constitute or imply its endorsement, recommendation, or favoring by the United States. Government or any agency thereof. The views and opinions of authors expressed herein do not necessarily state or reflect those of the United States Government or any agency thereof. 


\section{ADMINISTRATIVE ACTIVITIES}

- As a follow up to the June retreat, the analytical and sampling processes were evaluated and Dr. Michael Maskarinec has been scheduled to make a consulting visit in October. (See Appendix A for a summary report of the retreat activities.)

- The grant project directors and staff participated in the July 11 DOE/DOD exhibition held at the Hart Senate Building in Washington, DC.

- In late July, Dr. JoAnne Jackson, a SAIC consultant, conducted a site visit to assess the on-going research and to assist in better integrating this work into the OTD's plume focus area. Dr. Jackson visited for 3 days. She met with all of the cluster investigators, project directors and the director of the Center for Bioenvironmental Research. Additionally, she toured the Bayou Trepagnier site.

- In August, the grant continuation application with the FY 12-96 budget was prepared and submitted to DOE.

- In September, Dr. Charles Ide and Verna Lee met with Jeffrey Walker, the new DOE Program Manager, to discuss how the on-going research in this grant relates to the reorganization of DOE. And more specifically, how this administation should direct this project to meet DOE's objectives and priorities.

- A request for proposals was issued to Tulane and Xavier personnel to provide guidelines for the submission of proposed work to be funded from next year's budget.

- In September, Dr. Charles Ide and Verna Lee attended the "Resources Through Technology Conference '95 Solutions to Remediation in Butte, Montana." Verna Lee attended the Weapons Complex Waste Management \& Cleanup conference in Florida. 


\title{
COLLABORATIVE CLUSTER PROJECTS
}

\section{Biotic and Abiotic Studies on the Biological Fate, Transport and Ecotoxicity of Toxic and Hazardous Waste in the Mississippi River Basin}

\author{
A. Abdelghani, Y. Pramar, T. Mandal
}

\section{Objectives and Goals:}

The goal of this project is to assess the levels of xenobiotics in Devils Swamp and to study their biological fate, transport and ecotoxicity and ulitimately to estimate their potential toxicity to humans.

To accomplish this the project will: 1 ) assess the acute toxicity of individual xenobiotics and toxicity of organic compounds (hexachlorobutadiene (HCB) and hexachlorobenzene (HCBD)) on juvenile crayfish; 2) determine the biotic influence of temperature, salinity, $\mathrm{pH}$, oxidation-reduction potential, and sediment composition on the migration of xenobiotics and; 3 ) develop a pharmacokinetics model for xenobiotic absorption and storage, distribution and excretion by fish and crayfish.

\section{Accomplishments This Quarter:}

- Screening studies for long term exposure were completed and bioaccumulation studies on juvenile crayfish are in progress.

- Recent water, fish, sediment and vegetation samples collected by Dr. Bart are in the process of being analyzed for two organic compounds: HCB and HCBD; and for five inorganics: Arsenic, Cadmium, Chromium, Lead and Nickel.

\section{Publications and Presentations:}

Abdelghani, A.A., Pramar, Y.V., Mandal, T.K., Tchounwou, P.B., and Heyer,L.. Levels and Toxicities of Selected Inorganic and Organic Contaminants in a Swamp Environment. Journal of Environmental Science and Health, B30(5), (1995). 


\title{
Assessment of Mechanisms of Metal-Induced Reproductive Toxicity in Aquatic Species as a Biomarker of Exposure
}

\author{
M. Anderson, W. George, J. Preslan, K. Bundy \\ S. Sikka, K. Agrawal, B. Kamath
}

\section{Objectives and Goals:}

The objective of this work is to identify and quantify heavy metals and petroleum products (polyaromatic hydrocarbons) present in Bayou Trepagnier relative to remote control sites in the LaBranche Wetlands. Additionally the project will: 1) assess the uptake and bioaccumulation of metal and organic contaminants of interest in aquatic species in the field and in the laboratory; 2) evaluate the effects of these contaminants on reproductive function of aquatic species as potential biomarkers of exposure and;3) conduct periodic evaluation of sediment and water parameters (nutrients, sediment oxygen demand, productivity) to study seasonal and event related changes in Bayou Trepagnier and control sites.

\section{Accomplishments This Quarter:}

\section{Field Studies}

- An in situ experiment was conducted in which covered 6 foot long PVC pipes, embedded in the sediment, were used to create bayou microcosms stressed by conditions of reduced light, water flow and gaseous exchange. Water parameters were compared with those obtained March 1994. Seasonal differences were observed in water acidity, nutrient and oxygen profiles and temperature. No significant quantity of metals was released from the soil to the water.

- Analyses of waters and sediments collected in Bayou Trepagnier and control locations continued at intervals of 4 to 6 weeks. Data on nutrient levels, temperature, conductivity, oxygen levels and sediment oxygen demand. Compilation of the data for transfer to the project's GIS system continued.

- Oil and grease analyses of sediment-cores taken from sites in Bayou Trepagnier, Bayou Traverse, and Lake Pontchartrain demonstrated that a high concentration of these contaminants are present in the upstream sediments of Bayou Trepagnier.

- Analyses for Lead, Chromium, and polyaromatic hydrocarbons (PAHs) in sediment cores collected at 5 study sites in the LaBranche Wetlands including Bayou Trepagnier were conducted. Janet Preslan and Dr. James Bollinger, a post doctoral fellow at Tulane, developed the extraction and analysis procedures for 18 PAHs. Dr. Arthur Lee, post doctoral fellow at Xavier University, has been assisting with the analyses.

- Approximately 50 fish were collected from Bayou Trepagnier and Bayou Traverse (control site). Began analyses of contaminants present in the fish. In collaboration with Drs. W. Hartley, and A. Thiyagarajah, Dr. Anderson has continued the studies of gonads of fish from Devils and Tunica Swamps and the histopathology of fish from 
Bayou Trepagnier and Bayou Traverse sites.

- At one heavily contaminated site in Bayou Trepagnier the only fish species which has been caught is the spotted gar. It is believed that the gar are able to inhabit the area because of their ability to get oxygen from the water's surface in addition to getting oxygen through their gills.

- This group assisted Drs. Charles Ide and Elliot Horner's exposure-study of frogs in Bayou Trepagnier. Tissue analysis for metal and organic contamination for these began.

- Sediment cores over the length of Bayou Trepagnier were collected for organic analyses.

\section{Laboratory Studies}

- A study involving the exposure of female and male crayfish to hexavalent Chromium was conducted which involved the majority of the cluster membership. Crayfish were exposed to three different concentrations of hexavalent Chromium $(0.3,3.0$, and 30 $\mathrm{ppm}$ ) for various time periods for up to 7 weeks and then followed by a clearance period in clean water for 3 weeks. Crayfish were then evaluated by different members of the cluster for the following:

- Tissues of female crayfish were analyzed by atomic absorption spectrometry for Chromium concentrations in Dr. George's laboratory. Bioaccumulation of Chromium is time- and dose-dependant with the magnitude of tissue concentrations as follows: gills > hepatopancreas > exoskeleton > muscle > ovary $>$ hemolymph. However, Chromium does not bioaccumulate in the tissues as rapidly as Lead did in the previous Lead-exposure studies.

- Chromium speciation studies of the metal in gills, hepatopancreas and muscle of female crayfish are being perfomed in Dr. Bundy's laboratory. Results to date indicate a significant degree of conversion of the hexavalent Chromium to the less toxic trivalent state. The amount of the more toxic hexavalent Chromium seems limited to a plateau value which is independent of the exposure concentration or length of exposure.

- Dr. Kamath is using the above data for creating a biomodel of accumulation and distribution of Chromium in the crayfish.

- Histopathological study of crayfish tissues in Dr. Anderson's laboratory demonstrated damage to the gills and hepatopancreas with no damage to ovaries.

- Dr. Sikka evaluated the reproductive organs in Chromium exposed male crayfish. Exposure of male crayfish to high doses of Chromium for 4 weeks had no significant effect on body weights, vital organ weights or testicular 
weights. Sperm concentration was unaffected by the metal treatment. Superoxide dismutase (SOD), a free radical scavenging enzyme, was measured in the hemolymph of the Chromium-exposed males which demonstrated a significant decrease when compared to unexposed males. SOD activity may serve as a potential biomarker of metal toxicity in crayfish.

- Dr. Agrawal's laboratory has continued the work on the measurement of metallothionein (MT) protein in catfish tissues as a possible biomarker for metal contamination in this species. An ELISA assay has been developed. While measurement of MT in mammalian tissues has been successful, the data generated from catfish hepatocytes were found to be variable. Therefore, a quantitative western blot assay is being developed to measure the levels of MT in catfish tissues.

- Female crayfish were exposed to either $150 \mathrm{ppb}$ Lead or $300 \mathrm{ppb}$ Chromium for 4 to 7 weeks for acquistion of more data for completion of previous studies.

- The setting up of the catfish facility has been initiated.

- During this quarter, Dr. George's analytical laboratory ran the following analytical procedures in support of this project:

- Microwave digested 1375 crayfish tissue specimens.

- Analyzed 900 tissue specimens by atomic absorption spectrometry. Calculations and statistical evaluations were conducted.

- 390 wet chemistry analyses were performed.

- Analyzed 140 sediment specimens for oil and grease content.

- Digested and analyzed 75 sediment specimens by graphite furnace A.A. (200 runs).

- Began analysis for polyaromatic hydrocarbons in 75 sediment specimens.

- Investigators began work on 5 publications.

- In September Dr. George and Janet Preslan attended a meeting which included Corps of Engineers, U.S. Geological Survey, Environmental Protection Agency and the Louisiana Department of Environmental Quality. The focus of the meeting was the plans presently being considered to divert a portion of the Mississippi River water into Lake Pontchartrain for the purpose of restoring the low salinity conditions which have historically existed in the Lake. A major concern is the impact this diversion would have on the LaBranche Wetlands which contain both the contaminated and control sites being studied by this project. 


\title{
Hazardous Wastes in Aquatic Environments: Biological Uptake and Metabolism Studies
}

\author{
J. Barber, A. Apblett, H. Ensley, M. Fingerman, M. Fink, M. Polito
}

\section{Objectives and Goals:}

The goals of this cluster are to study the uptake, accumulation, metabolism, toxicity and physiological effects of various environmentally-important contaminants, inorganic and organic, in several wetland species that are interelated through food webs. Further, it is the goal of this project to investigate the potential for developing and linking chemical and biological methods of remediation so as to encapsulate bioaccumulated ions in stable wasteforms such as ceramics and/or zeolites.

\section{Accomplishments This Quarter:}

- Studies on the metabolism of 2,4,5-trichlorophenol to $\beta$-trichlorophenylglucoside by duckweed, Lemna gibba, have been completed. The toxicity, uptake and metabolism, by duckweed, of a mixture of chlorinated phenols (phenol, p-chlorophenol, 2,4dichlorophenol, 2,4,5-trichlorophenol, 2,3,4,6-tetrachlorophenol and pentachlorophenol) began. The data derived from using these chlorinated phenols singly and mixed will provide a comprehensive description of their metabolism by duckweed.

- The reductive dechlorination of 2,4,5-trichlorophenol by Lemna is being studied further. The 2,4,5-trichloroanisole was synthesized and used to investigate the manner in which dechlorination is accomplished. The data obtained to date suggest that glucosylation is the first step in the reductive dechlorination pathway.

- An investigation of the metabolism of aniline and n-butanol by $L$ gibba is proceeding. The isolation and purification of two aniline metabolites began.

- A study of the metabolism of naphthalene by $L$ gibba showed that it is converted to two more polar compounds, one major, one minor. A rapid screening of suspected metabolites has shown that they are not 1,4-naphthoquinone, $\alpha$-naphthol or $\beta$-naphthol so the identities of these metabolites are still unknown.

- A study of the effect and fate of 2,4-dichlorophenol in a simple two-step food chain consisting of duckweed, $L$. gibba , and the red swamp crayfish, Procambarus clarkii, was initiated. It has been shown that the plants covert the 2,4-DCP to its corresponding glucoside but that within seconds of this metabolite entering the gastric gland of the crayfish the glucoside was cleaved back to free 2,4-DCP and glucose. The metabolic and anatomic fate of the $2,4-\mathrm{DCP}$, in the crayfish, is being investigated further.

- The in vivo effect of Cadmium on ovarian maturation in P. clarkii has been investigated. One tenth microgram Cadmium injected per gram of body weight resulted 
in inhibition of ovarian maturation. The Cadmium injections were also able to inhibit the ovarian maturation that is ordinarily seen after injection of seratonin (5hydroxytryptamine).

- In vivo experiments, on $P$. clarkii, and using ${ }^{14} \mathrm{C}$ labeled leucine, are in progress. These experiments are designed to explain how Cadmium may affect the neuroendocrine center that produces the ovarian-stimulating hormone.

- Continued the investigation of uptake of thorium, by $L$ gibba from its growth medium, and used simulated duckweed extract, the feasibility of the removal of thorium from the plants by a variety of layered titanate materials.

- FeS was tested as an ion-exchanger for removal of Cadmium, Mercury and Lead from solution. It did this extremely well and competition experiments are currently being performed to determine selectivity. Cadmium-, Mercury- and Lead-spiked simulated duckweed extract is being treated with FeS to determnine the effectiveness of an integrated biological/chemical remediation process.

- It was determined that $\mathrm{FePO}_{4}$ is an excellent ion-exchanger for removal of actinides (thorium and uranium) from aqueous media. This material is definitely a promising barrier material candidate.

- Competition studies measuring the relative uptake of the heavy metal ions $\mathrm{Cd}^{2+}, \mathrm{Hg}^{2+}$ and $\mathrm{Pb}^{2+}$ versus $\mathrm{Ca}^{2+}$ into several zeolites have been performed. In the case of ZeoX and zeolite A-51, an approximate tenfold selectivity of heavy metal cations over $\mathrm{Ca}^{2+}$ was observed. Zeolite IE-95 was found to be realtively non-selective for heavy metals and further studies on this particular zeolite have been discontinued.

- A CVD system for the chemical derivatization of zeolites has been constructed. This apparatus is being used for encapsulation reactions whereby the metal-loaded zeolite will be chemically sealed. The reaction of phenylsilane at $110^{\circ} \mathrm{C}$ with $\mathrm{Cd}^{2+}$ and $\mathrm{Pb}^{2+}$ loaded ZeoX results in the blockage of $80 \%$ of the zeolite pores. The blockage of pores is being optimized as a function of silane exposure and temperature. In addition, zeolites are being derivatized for enhanced selectivity towards heavy metal ions (via sulfurization reactions).

- Solid state NMR and FT-IR studies of the reaction between $\mathrm{H}^{+}-\mathrm{ZeoX}$ and phenylsilane have been performed. The initial reaction of the zeolite with phenylsilane occurs at $60^{\circ} \mathrm{C}$ via reaction of an $\mathrm{Si}-\mathrm{H}$ bond of the silane. Further thermal treatment $\left(200^{\circ} \mathrm{C}\right)$ resulted in the loss of all $\mathrm{Si}-\mathrm{H}$ bonds and finally the loss of benzene.

\section{Publications and Presentations:}

Reddy, PS. and Fingerman, M. "Effect of Cadmium Chloride on Physiological Color Changes of the Fiddler Crab, Uca pugilator" was published in Ecotox. and Environ. Safety (1995), 31: 69 - 75. 
Devi, M. and Fingerman, M. "Inhibition of Acetylcholinesterase Activity in the Central Nervous System of the Red Swamp Crayfish, Procambarus clarkii, by Mercury, Cadmium and Lead" was published in Bull. Environ. Contam. Toxicol. (1995), 55: 746 - 750.

Reddy, PS., Katyayani, RV. and Fingerman, M. A manuscript describing the effects of Cadmium and Naphthalene on the neuroendocrine system of the fidler crab, Uca pugilator, was accepted for publication in Bull. Environ. Contam. Toxicol.

Fingerman, M., Devi, M., Reddy, PS., and Katyayani, R. A manuscript describing morphological changes in the hepatopancreas of crayfish exposed to the polluted environment of Bayou Trepagnier was accepted for publication in Amer. Zoologist.

Reddy, PS., Maheswruda, G. and Fingerman, M. A review article concerning the inpact of heavy metal exposure on the nervous and endocrine systems of crustaceans was accepted for publication in Zoological Studies.

Barber, JT., Sharma, HA., Ensley, HE., Polito, MA. and Thomas, DA. A manuscript describing the detoxification of phenol by Lemna gibba was accepted for publication in Chemosphere.

Devi, H., Thomas, DA., Barber, JT., and Fingerman, M. A manuscript describing the effects of Cadmium in an aquatic food chain involving duckweed and crayfish was accepted for publication in Ecotox. and Environ. Safety.

Two papers have been accepted for presentation at the Fall Meeting of the Nuclear and Environmental Technology Division of the American Chemical Society: "Layered Titanates as Sinterable Ion-Exchangers for Actinides" and "Incorporation of Radionuclides into SYNROC using Metal Organic Deposition".

\section{Ecological Sentinels of Aquatic Contamination In The Lower Mississippi River System}

H. Bart, Jr., P. Martinat, T. Sherry, S. Spahn, L. Thien, E. Ellgaard, M. Devall, C. Thomas, S. Latimer

Sub-Project I: Community and Trophic Responses of Fishes to Aquatic Contamination

\section{Objectives and Goals:}

The primary objective of this research project is to assess the ecological risk of contaminants from a hazardous waste site on the fish community of a floodplain swamp in the lower Mississippi River system. The ultimate goal of this research is to integrate data on community-level effects of aquatic contamination (population, trophic, and community indicators) with data on effects at the organism level and below (general health and condition indicators, histopathological indicators). 


\section{Accomplishments This Quarter:}

- Sampling trips in July and August yielded water and sediment samples and a total of 186 fish: 125 fish representing 20 species from Tunica Swamp (control area); and 61 fish representing 14 species from Devils Swamp (contaminated swamp). The two swamps continue to support comparable diversities of fish species. Comparisons of size/weight relationships in the two swamps are underway. Diets of most of the species are not well characterized.

Recent analysis of surface sediment samples from multiple sites within Devils Swamp confirms previous findings of the Tulane Environmental Health Science Laboratory there exists a contaminant plume grading from low parts per million (ppm) concentrations of HCB and HCBD just below the Brooklawn hazardous waste site to low parts per billion (ppb) concentrations near the Mississippi River outlet. Recent sediment analysis results also illustrate the nature of the suspected PCB contamination problem in the swamp.

Sub-Project II: Tree Cores as Biomarkers

\section{Objectives and Goals:}

The objective of this section is to utilize the tree-rings of baldcypress (Taxodium distichum $L$.) to record present and past pollution events by heavy metals and document growth trends in the Bayou Trepagnier and Devils Swamp ecosystems in Louisiana.

\section{Accomplishments This Quarter:}

- The entire quarter was devoted to data analysis and preparation of a manuscript. Sub-Project III: Effects of Environmental Contaminants on Colonial Wading Birds

\section{Objectives and Goals:}

The objectives of this section are: 1) to assess levels of Lead ( $\mathrm{Pb}$ ), Cadmium (Cd), hexachlorobenzene (HCB), and hexachlorobutadiene (HCBD) in food items retrieved from nestling wading birds; 2 ) to assess levels of the same contaminants in tissues of wading birds, specifically feathers, blood, guano, and eggs; 3 ) to measure nesting success and growth rates of one species in a contaminated and in a control colony; 4) to establish bioconcentration of contaminants in adult females by analyzing pollutant levels in eggs; 5) to determine which tissues in wading birds are the best indicators of heavy metal and/or organic pollutants in the food chain and; 6) to examine the effects of food chain contamination on nesting success and growth rates of wading birds.

\section{Accomplishments This Quarter:}

- Little Blue Herons in a contaminated site and in a control colony have been followed until all nests had fledged. 
- Samples of blood, feathers, and guano have been taken from nesting White Ibis in three different colonies.

- 43 samples each of egg shells, albumin, and yolk collected from eggs of Little Blue Herons and Great Egrets have been acid digested prior to metal analyses.

- 143 feathers, 126 guano, and 78 blood samples collected from nestling Great Egrets, Little Blue Herons and White Ibis have been acid digested for metal analyses.

- Egg contents have been analyzed for HCB and HCBD.

- Methods for organic analysis of guano, blood, and food items have been established.

- Growth rate data from Little Blue Herons in both colonies is currently being analyzed for differences between contaminated and control sites.

\title{
Publications and Presentations:
}

"Dendrochronology and Heavy Metal Deposition in Tree-rings of Baldcypress," was submitted to the Journal of Environmental Quality for publication.

\section{Bioremediation of Selected Contaminants in Aquatic Environments of the Mississippi River Basin}

\author{
S. Bhattacharya, H. Mielke, J. Bennett, J. Eckert, A. Englande, Jr., \\ R. Fulginiti, D. Grimm, V. Law, D. Mullin, J. Ross
}

\section{Objectives and Goals:}

The objectives of this project are: 1) to determine what environmental conditions are necessary for enchancement of natural biodegradation processes and whether it is feasible to apply the technology developed to field conditions; 2) to develop an user friendly biokinetic model which is applicable to field conditions; 3) to determine if the new fungal isolate Marasmius is is effective against a variety of contaminants (heavy metals and chlorinated hydrocarbons); 4) to incorporate the inorganic and organic data into the GIS data base to facilitate analysis of the results; and 5) by combining these multidisciplinary efforts, develop an integrated approach to bioremediation.

\section{Accomplishments This Quarter:}

- Research investigating anaerobic degradation of carbon tetrachloride (CT) and chlorophenols by methanogens and sulfate reducing bacteria continued. Biodegradation of pentachlorophenol (PCP), trichlorophenols and dichlorophenols by sulfate reducing bacteria and methane producing bacteria is under investigation. The 
ability of fungi and anaerobic bacteria to degrade chlorophenols is being studied. Continuous column studies demonstrated over a 99.9\% CT removal in 3 days. As expected, chloroform was observed as an intermediate. Modeling work continued. Additional data regarding degradation of carbon tetrachloride was collected using a stainless steel reactor to minimize losses due to volatilization. Leak testing and performance evaluation of the reactor was completed.

\title{
A Sensitive Rapid On-Site Immunoassay for Heavy Metal Contamination
}

\author{
R. Blake, D. Blake, G. Flowers
}

\section{Objectives and Goals:}

The principal goal of this focus group is to develop immunoassays for heavy metals that will permit the rapid on-site analysis of specific heavy metals in water and soil samples. Previous studies have shown that monoclonal antibodies to specific metal-chelate complexes may be obtained that permit the quantification of indium in the ppb range even in the presence of excess concentrations of other metals. This group seeks to extend these studies to develop immunoassays for target metals that include, but are not limited to, Lead and Chromium. Specific aims include: 1) to develop new immunoassays for metals that are priority pollutants; 2) to validate each new metal immunoassay by comparing the results with those obtained by atomic adsorption spectrometry and inductively coupled plasma spectrometry; 3 ) to test these new assays on samples collected at previously studied test sites and to initiate the development of field applications for the immunoassay; and 4) to initiate studies on the bacterial bioremediation of Lead and Chromium at contaminated test sites.

\section{Accomplishments This Quarter:}

- A monoclonal antibody directed against ionic Cadmium chelated with ethylenediaminetetraacetic acid (EDTA) was shown to be highly specific for Cadmium. Equilibrium binding measurements have been performed with each of 16 different soluble metal ions using a KinExA $A^{\mathrm{TM}}$ immunoassay instrument. Metals in this survey included those in the same row and column of the periodic chart as Cadmium, those with ionic radii within several percent of that of Cadmium, and those likely to be present in relatively high concentrations in environmental samples. In all cases, the monoclonal antibody showed the greatest affinity for chelated Cadmium. It is anticipated that these data will be useful in the development of immunoassays for ionic Cadmium.

- Proteins bearing covalently conjugated complexes of Lead (EDTA-Pb(II)) were synthesized, characterized, and delivered to the hybridoma facility at the LSU medical center. These Lead-chelate conjugates are required for the production and screening of monoclonal antibodies directed against ionic Lead. 
- New methods were sought to enable investigators to extract heavy metals from soil and sediment samples in the field without recourse to strong acids, high temperatures, or cumbersome equipment. A 5 minute incubation with EDTA extracted approximately $50 \%$ of the Lead from 4 dried samples derived from spoilbanks along Bayou Trepagnier. The concentration of EDTA used in these experiments is compatible with the immunoassay format currently under development.

- The fine Lead-bearing particulate matter formed when Xanthomonas maltophilia was exposed to ionic Lead was investigated by particle analysis techniques. The Lead biocolloids produced by bacterial action have been determined to be 50 to 150 nanometers in diameter and to bear considerable negative charge on the surface of the particle (as evinced by the $30 \mathrm{mV}$ of zeta potential on the colloid revealed by electrophoretic mobility measurements). It is anticipated that this information could be exploited in separation activities associated with possible bioremediation strategies.

\title{
Pore-Level Flow, Transport, Agglomeration and Reaction Kinetics of Microorganisms
}

\author{
L. Fauci, D. Gaver, P. Moore, K. Papadopoulos, B. Sharma
}

\section{Objectives and Goals:}

Understanding the detailed pore-level behavior of microorganisms through porous media is essential for the development of effective in situ bioremediation strategies. Integrated experimental and computational models of the pore-level behavior of microorganisms are being developed. The models will include the detailed analysis of convection and diffusion within the pores and the convection and chemotactic responses of swimming microorganisms to the local concentration gradients. Additionally, these models will include microbial adhesion to each other and the surrounding pore structure, and the reaction kinetics of these organisms to the toxic contaminant.

\section{Accomplishments This Quarter:}

- Robert Dillon, the postdoctoral researcher on this project, has been awarded an NSF postdoctoral fellowship to continue these studies at Tulane. He completed most of the development of biofilm aggregation models of microorganisms progressing through small pores using the immersed boundary method.

- Three graduate students, Mr. Dean Bottino (Mathematics), Mr. Zewen Liu (Chemical Engineering) and Mr. Darren Yap (Biomedical Engineering) worked on various aspects of this project.

- Dr. Herb Keller from the California Institute of Technology, visited in September and presented his work on numerical continuation methods for bifurcation problems (important in parameter studies). 
- Annette Johnson, Xavier University graduate student, is working on developing a code for solving reaction diffusion systems using the $\mathrm{ADI}$ method.

\title{
Publications and Presentations:
}

- Dr. Robert Dillon presented a talk entitled "Modeling Biofilm Processes Using the Immersed Boundary Method" to the immersed boundary group at New York University and at the Center for Biofilm Engineering at Montana State University.

- Liu, Z. and Papadouplous, KD. Unidirectional Motility of Escherichia Coli in Restrictive Capillaries". Appl. \& Env. Microbio. 1995, 3567-3570.

\section{Biomarkers of Exposure and Ecotoxicity in the Mississippi River Basin}

\author{
W. Hartley, T. Huang, E. Horner, C. Ide, M. Mizell, P. Obih, S. Phadtare, \\ R. Tompkins, A. Thiyagarajah, M. Welt
}

\section{Objectives and Goals:}

The goals of the project are: 1) to determine which biomarker responses reflect the combined toxicological interactions in frogs and fish exposed to mixtures of environmental contaminants typical of Devils Swamp and Bayou Trepagnier; 2) to determine which biomarker responses integrate exposure over-time. Biomarker responses integrating exposure over-time may indicate subacute, subchronic and chronic adverse ecological effects of mixtures of contaminants; and 3) to identify and characterize the most sensitive sentinel species based on biomarkers.

The specific hypotheses are: 1 ) histopathological response is a valid biomarker for exposure over time and the toxicological effects of mixtures of contaminants; 2) heavy metal and organic pollutants cause abnormal development and physiology in frogs in controlled laboratory tests; 3) pollutants in water and sediment samples will correlate with accumulations in tissues; 4) pollution levels in tissues will correlate with expression of biomarkers related to altered function in embryonic development, immune responses, and neural function; and 5) esterase enzymes are effective biomarkers of exposure in fish and frogs.

\section{Accomplishments This Quarter:}

\section{Histopathology of Fishes from Devils Swamp and Tunica Swamp}

- Histopathological examination of three species of gar fish and three species of buffalo fish collected from Devils Swamp and Tunica Swamp up to January 1995 were completed. Histochemical analysis of liver sections for the presence of iron began. 
Gar

- Began preparation on a manuscript on lesions in gar fish from Devils Swamp.

Buffalo fish

- Histochemical characteristics of eosinophils in the gills of buffalo fish have been completed. Began analysis of the number of eosinophils and the relative percentage of area occupied by these eosinophils using NIH image analysis methodology.

- Began histochemical analyses of buffalo fish livers for the presence of iron.

Microinjection of Medaka Fish Embryos with Devils Swamp Contaminants

- The results from the microinjection of medaka embryos with hexachlorobenzene were analyzed.

\section{Neurotoxicological and Immunological studies}

- Laboratory studies were carried out that showed that HCB, when applied to developing frog embryos in doses from $50-100 \mathrm{ppb}$, over the first several days of development, produced pronounced paralysis in tail musculature. Began study to determine if the focus of the paralysis lies in disruption of the muscle cell membrane, or if it lies in the ability of the motor neurons to release transmitter at the neuro muscular junction.

- Field studies involved placing adult frogs in cages at the headwaters of Bayou Trepagnier, a site known to contain hydrocarbon and metal contaminants. Other frogs were placed at a control site in Bayou LaBranche. Frogs were left for one week in the field and then were assayed in the laboratory for immune system activity. Both PHA and ConA tests for lymphocyte mitogen response showed immuno-suppression in frogs placed in the contaminated site compared to the control site. Brains from these frogs were analyzed using ELISA for interleukin-1 $\beta$ levels. Frogs from the contaminated site had levels of interleukin- $1 \beta$ approximately one-half of levels from control site frogs. Both mitogen lymphocyte assays and levels of interleukin- $1 \beta$ in the neuroimmune system of the brain indicate immuno-suppression in frogs at the contaminated site compared to frogs at the control site. This is not surprising because studies in the literature indicate that a variety of hydrocarbon contaminants can cause immuno-suppression in both animals and humans.

\section{Metabolism and Neurotoxicology}

- Certain enzymes, acetylcholinesterase ( $\mathrm{AChE}$ ), butyrylcholinesterase (BChE) and non specific carboxylesterase ( $\mathrm{CaE}$ ), levels were found to be significantly lower in the brain and liver of fish from Devils Swamp than fish from Tunica Swamp.

- Several chemicals (ie. hexachlorobutadiene, Cadmium, Mercury, and Lead) typical of Devils Swamp contaminants, were found to inhibit brain AChE and liver $\mathrm{CaE}$ activities in in vitro studies. 
- High resoluition isoelectric focusing gels indicated the presence of at least four $\mathrm{CaE}$ isozymes in the liver. These isozymes corresponds to a major esterase peak with a pI of 4.89 when the IEF gels were sliced and assayed with alpha-naphthyl acetate. Although the number of esterase isozymes in the liver of spotted gars from the two sites were similar, the intensity of the bands of gar from Devils Swamp were less intense than those from Tunica Swamp.

\title{
Publications and Presentations:
}

Mizell, M., Romig, E., Hartley, WR., and Thiyagarajah, A. Sex on the Brain but the Heart is not really in it: Developmental Heart Defects Associated with Aquatic Pollution and Microinjection of Hexachlorobenzene into the Japanese Medaka. Biological Bulletin October, 1995.

Thiyagarajah, A., Hartley, WR., Broxson, MW., and Major, SE. 1995. Pigments and Other Lesions in the Liver of Two Species of Buffalo Fish from the Mississippi River Basin. Presented at the Joint Meeting of the American Fisheries Society Fish Health Section and Eastern Fish Disease Workshop, Syracuse, New York, July 19-22.

Jaiswal, RG., Huang, TL., and Obih, PO., and Hartley, WR. 1995. Effect of Environmental Contaminants in the Mississippi River Basin on Carboxylesterases from Four Aquatic Species. To be presented at the Second SETAC World Congress, Vancouver, Canada, November 5-9.

\section{Natural and Active Chemical Remediation of Toxic Metals, Organics, and Radionuclides in the Aquatic Environment}

\author{
G. McPherson, P. Pintauro, S. O'Connor, J. Zhang, R. Gonzales, \\ V. John, G. Flowers
}

Sub-Project I: Metal Sediment Interactions at the Fresh-Salt Water Interface

\section{Objectives and Goals:}

The purpose of this study is to investigate the adsorption and desorption of heavy metals under various environmental conditions. Because the Delta region of the Mississippi River is characterized by a dynamic fresh-salt water interface, large changes in the concentration of heavy metals at this interface may occur as a result of the fluctuating $\mathrm{pH}$ and salinity. The seasonal changes in the river level may cause the wetland water which contain high concentrations of natural organic material to mix with river water.

\section{Accomplishments This Quarter:}

- Research has been focused on the effect of natural organic materials-- fulvic and humic acid -- on the $\mathrm{Pb}^{2+}$ and $\mathrm{Cd}^{2+}$ adsorption and desorption on the montmorillonite under the different conditions. The main results are summarized as follow: 
- When fulvic or humic acid (FHA) is present, the amount of $\mathrm{Pb}^{2+}$ and $\mathrm{Cd}^{2+}$ adsorbed onto the montmorillonite will decrease with increasing FHA concentration.

- The effect of FHA on the $\mathrm{Pb}^{2+}$ and $\mathrm{Cd}^{2+}$ adsorption is more apparent under neutral $\mathrm{pH}$ than at low $\mathrm{pH}$. The amount of adsorbed $\mathrm{Pb}^{2+}$ and $\mathrm{Cd}^{2+}$ decreases more rapidly at a near neutral $\mathrm{pH}(6.5)$ than an acidic $\mathrm{pH}(3.0)$ while increasing the FHA concentration.

- It is known that increasing the ionic strength results in a decrease in the adsorption of the heavy metal. It is observed further in this research that when the ionic strength is increased to $0.1 \mathrm{M}$ by adding $\mathrm{NaCl}$ or $\mathrm{NaNO}_{3}$ to the samples, the effect of FHA on $\mathrm{Pb}^{2+}$ and $\mathrm{Cd}^{2+}$ adsorption will decrease. The curve of metal adsorption amount versus the FHA concentration will become asymptotic.

- Particle size analysis showed that $\mathrm{NaCl}$ resulted in particle flocculation when the FHA and montmorillonite coexist in aqueous solution.

- No obvious difference was observed between the effect of $\mathrm{NaCl}$ and $\mathrm{NaNO}_{3}$ on the $\mathrm{Pb}^{2+}$ and $\mathrm{Cd}^{2+}$ adsorption under identical conditions.

Sub-Project II: Heavy Metal Chemistry of Bayou Trepagnier

\section{Objectives and Goals:}

The purpose of this project is to determine the metal sequestering capacity of acid volatile sulfides in the bottom sediments of Bayou Trepagnier.

\section{Accomplishments This Quarter:}

- This quarter considerable effort was expended to characterize the water chemistry of the bayou after diversion of the Shell Norco effluent into the Mississippi River. Specifically, there is concern that changes in the water chemistry of the bayou might result in the release of metals into the water column. To this end, a four-day, round-the-clock monitoring of water quality parameters in the bayou was carried out. A summary of findings is below:

- The average dissolved oxygen of the water column has increased in the upper part of the bayou. The increase in dissolved oxygen is due to increased inflow of oxygenated water from Engineer's Canal. The lower dissolved oxygen content observed below station 60 is probably due to the decomposition of floating aquatic vegetation that was particularly heavy in this area during spring and summer. It was also noted that inflow of water from the adjacent swamp results in a dramatic decrease in the dissolved oxygen content of the water column in the vicinity of station 80. This suggests that the low dissolved content of water in the middle of the 
bayou is probably due to high organic loading from the swamp rather than from organic pollutants in the bayou itself.

- The average $\mathrm{pH}$ of the bayou decreased about 1 standard unit from 7.6 to 6.7. The decease in average $\mathrm{pH}$ did not result in metal release from the bottom sediments.

- The salinity and temperature profiles are more normal in that both salinity and temperature now decrease upstream.

\section{Sub-Project III: Polargraphic Assay of Heavy Metals}

\section{Objectives and Goals}

The objectives of subproject are: 1) to develop analytical methodology (mainly based on polarographic methods) useful for identification of pollutants present (mainly heavy metals) and measurement of their concentrations in water, sediment, and biota; and 2) to apply these techniques to measuring heavy metal concentration and speciation in Bayou Trepagnier and to understanding the factors which affect them.

\section{Accomplishments This Quarter:}

- Worked on the development of polarographic methodology suitable for in situ measurement of pollutant concentrations in the field. Tests were conducted with a graphite sensing electrode (replacing the Mercury drop which is used in the lab for this purpose). The first tests conducted, using Lead standards in a citric acid supporting electrolyte, were very promising and indicated that this basic approach is sound. Many different polarographic methods were examined for their suitability. The one found optimum was cyclic voltammetry. Interestingly, another method, differential pulse polarography, has been found to be most useful in this project's lab tests with the Mercury drop.

- The next series of tests involved testing of an actual sample of soil from Bayou Trepagnier which was known to contain high Lead levels. Metal extraction was done using methods which easily could be conducted in the field (rather than techniques used in a laboratory setting). These involved placement of the sample in hydrochloric acid, shaking for 5 minutes at room temperature, subsequent filtration, and testing with citric acid. A high Lead level was found with this method, as would be expected from analysis of such a soil sample.

- Tests with graphite electrodes directly placed in a sample of Bayou Trepagnier water were less definitive but gave some evidence of possible peaks associated with polarographic reduction of Lead. Such a method is more difficult than the test with the soil, due to a much lower concentration of Lead in the water. A possible solution to this difficulty is to increase the surface area of the electrode to allow higher currents to be measured. Experiments have been conducted in which the surface area of graphite exposed to the electrolyte has been increased, and the current appears to scale accordingly. This is a promising development, and further intensive efforts in the future are planned to develop in situ water analysis methods. 
- Besides the field sensing experiments, other activities have mainly involved planning for a second series of tadpole exposure tests, this time involving chromium, rather than Lead. Trivalent chromium sorption to kaolin, as influenced by $\mathrm{pH}$ has been the main focus of efforts this quarter.

Sub-Project IV: Chemical Separation and Remediation Processes: Remediation of Aromatics by a Chemo-Enzymatic Method

\section{Objectives and Goals:}

The focus of this sub-project has moved from a basic study of Fenton mechanisms for advanced oxidations to the practical problem of remediation of Bayou Trepagnier sediments. The objective of this phase of the work is essentially to apply an advanced oxidation technology to a practical situation. Initial results on treatability are promising but complete analysis of the reaction products are still lacking and further work will be done.

\section{Accomplishments This Quarter:}

- The experiments involve analysis of dissolved and adsorbed organics before and after treatment with the Fenton reaction. A variety of analytical techniques are employed; these include GC/MS, elemental analysis, NMR, FTIR and fluorescence spectroscopy. Both soluble iron species and iron minerals are used as Fenton catalysts and a quantitative analysis of $\mathrm{H}_{2} \mathrm{O}_{2}$ requirement is carried out. Reaction rate comparisons between soluble iron species and iron minerals as catalysts are also studied.

Sub-Project V: Chemical Separation and Remediation Processes: Metal-Ion Sequestering Polymers and Phosphate-Based Microporous Solids

\section{Objectives and Goals}

To develop membranes that can be used to separate radionuclides from radionuclide waste.

\section{Accomplishments This Quarter:}

- The work has focused on the sulfonation of poly [(4-ethylphenoxy)(phenoxy) phosphazene] in the dry film form. For this purpose, photocrosslinked membrane samples were prepared with nominal benzophenone content $10 \mathrm{~mol} \%$ and an experiment was set up to investigate the sulfonation degree, using seven different sulfonating agents: sulfuric acid and silver sulfate, a 2:1 mixture of sulfuric acid and ethanol, acetyl sulfate, a complex of sulfur trioxide: dioxane, chlorosulfonic acid, a mixture of chlorosulfonic acid and ether, and sulfur trioxide.

- The effect of those agents was quantified by measuring the ion-exchange capacity of the resultant films. The highest sulfonate concentration in the membranes was obtained when either sulfur trioxide or acetyl sulfate were used $(0.60$ and $0.35 \mathrm{mmol} / \mathrm{g}$, respectively). However, the sample sulfonated with sulfur trioxide suffered severe cracking. The current 
research is directed at eliminating this effect and increasing the final ion-exchange capacity to $1 \mathrm{mmol} / \mathrm{g}$.

- In a parallel study, work has been expanded to include two new polyphosphazenes: poly[(3-methylphenoxy)(phenoxy)phosphazene] and poly[(4-methylphenoxy)(phenoxy) phosphazene] polymers. The latter polymer, in particular, shows significant amount of crystallinity and films with good tensile strength were cast from THF solutions. Currently the photocrosslinking and sulfonation of this polymer are being investigated.

\title{
Publications and Presentations:
}

McCormick, M., Xu, X., John, VT., McPherson, GL. "Coupling Chemical and Enzymatic Oxidations with Immobilized Catalysts", ACS Conference on Emerging Technologies in Hazardous Waste Management, Atlanta, September 1995.

This research has been presented at the ACS conference on Emerging Technologies in Hazardous Waste Management in September, 1995, and is being written up for publication.

\section{Expert Geographical Information Systems for Assessing Hazardous Wastes in Aquatic Environments}

\author{
J. Regens, R. Bakeer, M. Barber, B. Belkhouche, J. Hughes,
} A. Rene, L. White, J. Wright

\section{Objectives and Goals:}

The primary objective involves the design and application of GIS to evaluate key indices of heavy metals bioaccumulation and histopathological effects on selected fish species in the Devils Swamp and Bayou Trepagnier ecosystems to integrate data collected by other project clusters. More specifically, project element \#1 (Dr. Regens' group) will construct a chemical and histopathological database, develop coverages, and perform spatial analyses for Devils Swamp. Project element \#2 (Dr. Bakeer's group) will perform parallel tasks to support the primary objective for Bayou Trepagnier.

\section{Accomplishments This Quarter:}

- Data was requested from all investigators analyzing Devils Swamp and Bayou

Trepagnier samples. Only one cluster group provided data this quarter and this data has been incorporated in the GIS.

- General informational data was collected from state and federal agencies.

- Entry of the field data and chemical analyses in fish tissue for Devils Swamp into the GIS database is complete. 
- An electronic format has been agreed upon for submission of field data and histopathological data in fish tissue. This will expedite the transfer of data between groups in the future.

- A 1:100,000 scale map of Devils Swamp has been constructed. In order to improve the resolution of the area, the base map features of a 1:24,000 scale map are being digitized.

Data quality objectives have been developed to screen chemical and histopathological data for suitability for inclusion in the GIS database.

- In 1994, a GIS lab was established in the Uptown Campus through this grant. Renovations to the lab were completed in the summer of 1995. The laboratory consists of Sun workstations running under Unix operating system. The main GIS software used is ARC/Info by ESRI. Peripherals available in the laboratory include digitizing tablets, plotters, color printers, laser printers, running on this Unix based system.

- Work on a prototype GIS system has progressed with a graduate student incorporating geology, hydrology, land use, topography for both Devils Swamp and Bayou Trepagnier. A total of 4,825 data fields have been incorporated into the system.

- A second GIS project has been completed by a undergraduate student. The PC based system was developed to store and manipulate geotechnical data at a given site. The work was done as an undergraduate honor thesis.

- At Xavier, new computer equipment and software compatible with the Tulane GIS was purchased. Training to use the software began and data transfer between the ICP and GIS computer was established. 


\title{
EDUCATION PROJECTS
}

\section{Enhancement of Environmental Education at Tulane and Xavier Universities}

\author{
S. O'Connor, L. White, S. Bhattacharya, J. Bennett, M. Zimmerman
}

\section{Objectives and Goals:}

The goal of the environmental education initiative of Tulane and Xavier Universities is to develop a comprehensive environmental education program to produce graduates who can successfully carry out the Department of Energy's mission of environmental restoration and waste management. A major objective of the initiative is to attract minority students into environmental careers. The environmental education programs at the two universities will ultimately range from primary school instruction through graduate level study, and to the continuing education of those in the workplace. The education cluster project supplements this grant's research cluster projects by attracting students into the environmental studies/sciences and providing academic programs relevant to the Department of Energy. The infrastructure for facilitation and coordination of programs is in place, with representatives from each school working together to build on existing strengths and resources within the four schools at the two universities.

\section{Accomplishments This Quarter:}

\section{Curriculum Development:}

- Seven environmental courses are being offered at Xavier during Fall Semester '95: Environmental Biology (Biology), Instrumental Methods of Analysis (Chemistry), Microeconomics (Economics), Environmental Literature (English), Personal and Environmental Health (Health and Physical Education), Calculus III (Mathematics) and Environmental Policy (Political Science). The Center for Environmental Programs (CEP) asked all faculty to encourage students to enroll in these courses.

- Environmental Studies courses taught at Tulane University in the Summer 1995 Session were:

General Biology, General Biology Lab, and Microbiology (Cell and Molecular Biology); General Chemistry, General Chemistry Lab, General Chemistry II, and General Chemistry II Lab (Chemistry); Microeconomics (Economics); Intro Physics I, and Intro Physics II (Physics); and Global Environmental Politics (Political Science Department).

- Environmental Studies Courses currently being taught at Tulane in the Fall 1995 Semester are:

General Biology, General Biology Lab, Microbiology (all Cell and Molecular Biology); Diversity of Life, Environmental Biology, Diversity of Life Lab, General Ecology, 
Invertebrate Paleontology, Biology of Invertebrates, Biogeochemical Cycling in Ecosystems, Estuarine Ecosystem Dynamics (all Ecology, Evolution and Organismal Biology); General Chemistry, General Chemistry Lab, Industrial Toxicology, Physical Geology, Intro Physics I (all Physics); Organizational Issue Management,

Environmental Communication (both Communications); Microeconomics (Economics); Politics in Environmental Health (Environmental Health Sciences); Intro to Political Economics (Political Economy); Environmental Politics (Political Science); and National Landscape/Built Form (Architecture).

- A meeting of the Internal Grants Committee (IGC) was held on July 7, 1995 to review three faculty mini-grant proposals for course development/infusion. The proposals considered were 1) Dr. Michelle Levy 's (Chairperson/ Professor, English) proposal entitled "Creating a Course in Environmental Literature;" 2) Dr. Levy's proposal entitled "Greening the Across the Curriculum (ACT) Program;" and 3) Dr. Raquel Mesa's (Assistant Professor, Mathematics) proposal entitled "Environmental Issues in Introduction to Differential Equations." Dr. Levy's first proposal was approved for course development while her second proposal was approved as an "outreach" project. The committee also approved providing one computer to Dr. Levy's for support of the proposed work. Dr. Raquel Mesa's proposal was deferred pending receipt of additional information.

\section{Student Development:}

- Two Xavier University faculty members, Drs. Royal Saunders (Biology) and Tujuanda Jordan-Starck (Chemistry), were appointed to serve as CEP faculty liaisons for their respective departments. The liaisons will assist the CEP in recruiting students for enhanced training in environmental careers.

- At Xavier, fifty-nine (59) applications for environmental scholarships have been received. These were reviewed by the Xavier Environmental Education Committee. The scholastic records of all current scholars were also reviewed for continuation of award. Committee members were provided scholarship guidelines, announcements of scholarship requirements, and applicants' student records. A list of recommended recipients was submitted to the Director of the CEP (Dr. Sally O'Connor), the Dean of the College of Arts and Sciences (Sr. Monica Loughlin), and the Vice President for Academic Affairs (Dr. Antoine Garibaldi).

- The Tulane University LAS Environmental Education Committee 1) distributed the brochure on the interdisciplinary Environmental Studies program among Tulane students and faculty; 2) distributed questionnaires among Tulane faculty with environmental research interests for possible collaboration with the Environmental Studies program; and 3) formally recommended the establishment of an Environmental Science Graduate Program to the Tulane Graduate Council. The LAS Environmental Education Committee held a meeting on September 11th.

- The Tulane University LAS Environmental Education Committee 1) obtained approval for the establishment of an internship within the Environmental Studies program and developed a list of available internship opportunities for interested students; 2) Professors Zimmerman and Bennett and Christine Murphey met with Jane Polenko, Student Green Club President, and planned several ways to form liaisons between the student organization and Environmental Studies. 
- At the May 1995 Xavier University Graduation Ceremony, eight of the 1994-95 environmental scholars were awarded baccalaureate degrees. They included Tamara Mosby (Philosophy, Magna Cum Laude, LIFE Scholar) and Lauren Nicholas (Communications, LIFE Intern). During the summer, Tamara held an intership position with the Clean Water Act (CWA) in Pittsburgh, as a member of their telephone canvassing team, while Lauren worked with the Housing Authority of New Orleans on a self-help project for local residents. Currently, Tamara is a law school student at the University of Texas - Austin, and Lauren has accepted a position at the Deep South Center for Environmental Justice at Xavier University.

- A listing of the titles of the research projects and XU faculty mentors for all continuing LIFE scholars/interns during the 1995-96 academic year follows.

- Randy Dorsey, Project: "Isolation of Components of Mitracarpus Scaber (MISCA), a Natural Product," Faculty mentor: Dr. Richard Ochillo, Pharmacy

- LáMoyne Williams, Project: "The Distribution of Lead, Cadmium and Zinc in Urban Environments," Faculty mentor: Dr. Howard Mielke, Pharmacy

- Tiffany Zeno, Project: "Hilda's Garden: The Impact of Toxic Waste Dumps in an Urban Bayou Environment," Faculty mentor: Dr. Stephen Duplantier, Communications

- Shea Conway, Project: "Environmental Concerns of Citizens About Risks Associated With a DOE Facility at Savannah River Site," Faculty mentor: Mr. Stephen Peychaud, Environmental Programs.

- The Center for Environmental Programs resumed monthly meetings with XU Environmental Scholars to apprise them of information related to their scholarships and to obtain regular updates on their research projects.

- LáMoyne Williams (Biology ‘96, LIFE Scholar) and his faculty mentor, Dr. Howard Mielke (Associate Professor, Pharmacy) attended an international conference, entitled "Lead - A Community Concern," on July 5 - 7, 1995, in Trail, British Columbia, Canada.

\section{Seminars Held / Planned}

- On the Bayou Sauvage, and Career Opportunities in the Field of Wildlife Biology, presented by Mr. Pon Dixson, Refuge Manager at Bayou Sauvage National Wildlife Refuge (Sept. 19).

- Surviving the Internship: Who's Responsible, presented by Mr. Curtis Nettles, University Programs Specialist for Battelle Pacific Northwest Laboratory (October 10).

- Hypertension and the Environmental Relationship, presented by Dr. Edward G. Smith, Assistant Professor of Molecular Biology, Hampton University (November 7).

- War on the Environment, presented by Robbie Cox, National Sierra Club President, UNC, Chapel Hill. Michael Zimmerman was a member of the panel discussion that followed (October 12). 
- Estrogens in the Environment: A Metaphor for the Center for Bioenvironmental Research from Turtles to People, Reception for Environmental Studies students and the Green Club (October 30).

- Mississippi Waterways, Tulane faculty, (Summer 1996).

\title{
Graduate Program in Bioenvironmental Studies
}

\author{
S. Landry, M. Gerber, A. Brody
}

\section{Objectives and Goals:}

The goal of this project is to train a Ph.D. scientist for a career in bioenvironmental research using modern molecular and cellular biological techniques. Funds from this grant support a graduate student assistantship and travel expenses for the student to attend a meeting related to environmental research.

\section{Accomplishments This Quarter:}

Brian Foy, a first-year student, enrolled at Tulane in the Interdisciplinary Program in Molecular and Cellular Biology. Mr. Foy and the P.I. are in the process of identifying an appropriate research conference for him to attend in the Spring or Fall of ' 96. 


\title{
INITIATION PROJECTS
}

\section{Flocculation Studies In Environmental Processes}

\author{
E. Eschenazi , R. Effiong, B. Das
}

\section{Objectives and Goals:}

The objective of this project is to study flocculation phenomena in suspensions and emulsions, resulting from the process of aggregation of suspended particles. Flocculation is not only a determining factor in natural environmental processes, but also constitutes a tool for the cleaning of hazardous waste waters which contain suspended solids and emulsified oils. Understanding flocculation kinetics in various regimes is crucial to design proper remediation.

\section{Experimentally}

a. Multi-angle Light Scattering

One of the fundamental experimental techniques being used to study flocculation kinetics is light scattering. This technique allow for measurement of the Particle Size Distribution (PSD), its temporal evolution as function of heavy metal concentration as well as $\mathrm{pH}$ and concentration of indifferent ions (e.g. $\mathrm{K}^{+}$and $\mathrm{Cl}^{-}$).

b. Analysis of metals in the emulsions

Divalent ions specifically adsorb on the surface of suspended particles, thus playing a pivotal role in promoting coalescence. It is therefore important to know how certain metals such as $\mathrm{Ni}^{++}$and $\mathrm{Pb}^{++}$partition between the bulk aqueous solution and the surface of the emulsion droplets before and after the aggregation. Spectroscopic techniques, such as Atomic Absorption Spectroscopy (AAS), FTIR and ICP are used to trace metals in the solutions.

\section{Theoretically}

At the theoretical level, the aggregation kinetics are being studied by using computer simulation tecchniques. In particular a Monte-Carlo techniques will be used to investigate the collisional probabilities in concentrated emulsions. The experimental results will be compared with the calculations to develop a consistent predictive tool for flocculation kinetics in various regimes.

\section{Accomplishments This Quarter:}

- Samples of $n$-hexadecane/water emulsions have been prepared by Dr. R. Effiong and her chemistry student, Chris J. Watts in Dr. K. Papadopoulos Laboratory in the Department of Chemical Engineering at Tulane University. 
- Experimental studies of flocculation processes have been initiated using the recently computerized laser light scattering apparatus purchased from Brookhaven Instruments (model BI-200SM Goniometer System). The instrument was in the Department of Physics in July 1995 at of Xavier University.

- A sophomore engineering student who worked part-time during the summer with Dr. Biman Das on the calibration of the instrument will continue working in the Fall semester.

- The light scattering apparatus was tested by measuring particle sizes and particle size distributions of known samples such as certified latex from the Duke Scientific, oil-inwater emulsions. The results obtained were satisfactory. After this preliminary testing a systematic study of the emulsions prepared by Dr. Effiong and Chris J. Watts began. Preliminary measurements indicate particle sizes ranging from 382 to $778 \mathrm{~nm}$ for emulsions not containing surfactant and 255 to $272 \mathrm{~nm}$ for those with surfactant and analyzed with the light scattering apparatus.

- Dr. Effiong and Chris J. Watts, a Xavier student, studied the heavy metal baseline content of the emulsion by the use of the inductively coupled plasma instrumentation. The results showed that the reagents which were used in the preparation of the emulsions were devoid of heavy metals. They are also presently studying the stability of the emulsions. These studies will be coupled with the particle size measurements of the same samples.

- Dr. Eschenazi continued studies of three dimensional Monte-Carlo simulation to investigate the collisional probabilities in concentrated emulsions.

- Dr. Eschenazi collaborated with Dr. K. Papadopoulos (Tulane) and two students Dwana Bush (Xavier) and S. Deshiikan (Tulane) in a study of the effects of Brij58,CTAB and SDS surfactants on the dynamical surface tension at the slowly dilating n-Dodecane-Water Interface

\title{
Publications and Presentations:
}

Deshiikan, SR., Bush, D., Eschenazi, EV., Papadopoulos, K." Brij58,CTAB and SDS at the Slowly Dilating $n$-Dodecane-Water Interface" submitted to Colloids and Surfaces.

\section{Collaborative Research With the Institute of Radioecological Problems in Minsk: Mathematical Modeling and Computer Simulations on the Fate and Transport of Radionuclides in Belarus Following the Chernobyl Catastrophe}

\author{
E. Michaelides, K. Koutsougeras, S. Ramer, D. Sailor
}

\section{Objectives and Goals:}

To formulate the problem of aquatic transport in the Iput River, and educate the two Byelorussian students in the numerical methods of transport of radionuclides. 


\title{
Accomplishments This Quarter:
}

- The HEX-6 code on the aquatic transport of sediment was received from Oak Ridge National Laboratory (ONRL) and students began working simple transport cases with it.

- Dr. Antoinette Brenkert, an ORNL environmental scientist, gave a presentation on the features and use of the HEX- 6 code. She met with the students who will use the code.

- The computations on the atmospheric plume and the lift-off of particles was completed.

- The Belarus collaborators provided data on the particles lifted in forest fires. These were incorporated in the presentation mentioned below.

- The systematic categorization of the data needed for the Iput River project continued.

\section{Publications and Presentations:}

A short paper was presented in the ASME 7th International Symposium on Gas-Solids Flows. The paper also appeared in a volume of papers published for the Symposium.

\section{Use Of Protein Engineering To Create Cytochrome P450 102 Isozymes With Novel Catalytic Activities.}

\author{
D. Mullin
}

\section{Objectives and Goals:}

The goals of this research project are to use protein engineering methods to construct cytochrome P450 isozymes with designed activities that will enhance the natural ability of bacteria to degrade recalcitrant organic pollutants that are present in the environment. Attention is currenlty being focuse on developing pyrene hydroxylases and dehalogenases for use as tools for bioremediation.

\section{Background}

The cytochromes $\mathrm{P} 450$ are a class of heme-containing enzymes with diverse biological functions that include essential steps in intermediary metabolism and development; these enzymes also play key roles in eliminating environmental pollutants from biological systems. More than 100 P450 enzymes have been characterized, and these oxidize a wide variety of aliphatic and aromatic compounds. One feature that all P450 enzymes share is the presence of a thiolate coordinated b-type heme which is the reactive center of all such enzymes, and thus, the substrate specificity and reactivity of a particular enzyme results 
from the unique geometry and chemical character of the substrate binding site which is determined by the unique amino acid sequence of a particular protein. It therefore seems to be a reasonable assumption that by making appropriate changes to the amino acid sequence of a particular P450 enzyme, one should be able to change its substrate specificity and reactivity.

This experimental approach uses site directed mutagenesis to introduce specific alterations in the amino acid sequence of the cytochrome P450 102 of Bacillus megaterium $(1,2)$ in order to reshape the substrate binding channel and active site. P450 102 is unique because it has the $\mathrm{P} 450$ monooxygenase and heme reductase activities in the same polypeptide chain whereas all other known P450 monooxygenases require a separate P450 reductase protein. This unique feature of P450 102 makes it an attractive isozyme for our purposes because the required $\mathrm{P} 450$ reductase activity is automatically co-introduced with the oxidase. This last feature should, thus, facilitate the expression of P450 102 isozymes in various (appropriate) species of bacteria in which the ability to degrade environmental pollutants is of interest.

\section{Accomplishments This Quarter:}

- The investigation of how the natural substrate (long chain fatty acids) binds to wild type and mutant P450 102 isozymes has helped to guide the investigators in changing it from a fatty acid hydroxylase into a polycyclic aromatic hydroxylase that hydroxylates pyrene and benzo[a]pyrene which are environmental pollutants. These results demonstrate that protein engineering methods can be used to dramatically change the substrate specificity of P450 102, and it opens the door to allow for creation of designed isozymes that have other novel catalytic activities.

- Steady progress was made in dissecting the substrate binding domain (3) of the cytochrome P450 102 using site directed mutagenesis. Investigators began testing of the role of additional amino acid residues in substrate recognition.

- The use of computer-aided molecular modeling has been enlisted to better visualize and obtain a quantitative understanding of how the investigator's mutant isozymes recognize their new substrates.

- A detailed biochemical analysis of several mutant isozymes began. F87V, F87Y, F87A, T268S and T268V were overproduced in Escherichia coli, and purified to homogeneity by column chromatography. The purified mutant enzymes were assayed for their spectral and kinetic properties (specific activity $V_{\max }, \mathrm{K}_{\mathrm{m}}$ ) and compared to the wild type enzyme.

- Work began on the design of P450 102 isozymes that have dechlorination activities. A mutant strain BM312 (F87A) was constructed. This strain appears to actively dechlorinate tetrachloroethylene. The process of identifying the product(s) of this 
dechlorination reaction began. This work is being done in collaboration with $\mathrm{Dr}$. William Alworth's lab (Chemistry Department, Tulane University).

- A new graduate student, Willey Caffey, began his dissertation work which will involve testing the activity of mutant isozymes in vivo to determine if they facilitate degradation of pyrene, or dechlorination of tetrachloroethylene.

\title{
Publications and Presentations:
}

In collaboration with Dr. William Alworth's lab, a manuscript describing the new P450 102 polycyclic aromatic hydroxylase was prepared. This manuscript was submitted to Archives of Biochem. Biophys. and a response to the reviewers' comments are in preparation.

\section{References}

1. Nahri, LO. and Fulco, AJ. 1986. J. Biol. Chem. 261:7160-7169.

2. Nahri, LO. and Fulco, AJ. 1987. J. Biol. Chem. 262:6683-6690.

3. Ravichandran, KG., Boddupalli, SS., Haseman, CA., Peterson, JA., and Deisenhofer J. 1993. Science 261:731-736.

4. Xia, Q., Kang, L., Alworth, WL., Liu, HM., Zhao, W., and Mullin, DA. A SiteSpecific Mutant of the Bacterial Cytochrome P450 102 (BM-3) Posessing a New Capability to Catalyze the Hydroxylation of Polycyclic Aromatic Hydrocarbons Pyrene and Benzo[a]pyrene. (Submitted to "Archives of Biochem. Biophys", 695).

\section{Reusable Synthetic Membranes for the Removal of Aromatic and Halogenated Organic Pollutants from Waste Water}

\author{
C. Li, H. Ensley
}

\section{Objectives and Goals:}

To study new methodologies for synthesizing membrane for use in removing aromatic and halogenated organic pollutants from waste water.

\section{Accomplishments This Quarter:}

- Another method to couple two aldehydes has been developed. During this study, an unusual, previously unknown, regioselectivity of the coupling reaction was observed. This selectivity has been explored further with different substrates and more detailed experimental results. This finding is theoretically important in understanding the fundamental basis of such type of reactions. 
- A mono aldehyde of beat-cyclodextrin was prepared. The solubility and other properties of the compound were studied.

- Coupling of this aldehyde in water was carried out and the investigator began analyzing the result.

\title{
Publications and Presentations:
}

A paper has been submitted to Tetrahedron Letter; and it is now considered for publication upon some minor revisions.

\section{Xavier Analytical Analysis Support}

\author{
H.W. Mielke
}

\section{Objectives and Goals:}

The goal of this project is to provide an analytical support laboratory located at the the Xavier campus site which will provide the necessary analyses of inorganics in samples collected for the grant's swamp sites. To attain this goal the lab will work on the following objectives: 1) assess and develop appropriate sample preparation techniques; 2) provide training to improve skills in operating the analytical instruments being used; and 3 ) run analyses of samples as requested by this grant's investigators.

\section{Accomplishments This Quarter:}

- A study of 22 sediment samples with a wide range of metal contamination was conducted to compare hot concentrated $\mathrm{HNO}_{3}$ microwave digestion and the room temperature $1 \mathrm{M} \mathrm{HNO}_{3}$ Chaney-Mielke extraction methods. The results were extremely strongly associated ( $\mathrm{P}$-values ranging from $10^{-6}$ to $10^{-9}$ ) for $\mathrm{Cd}, \mathrm{Cu}, \mathrm{Mn}, \mathrm{Pb}$, and $\mathrm{Zn}$, and strongly associated $\left(\mathrm{P}\right.$-value $\left.=10^{-2}\right)$ for Se. The association $(\mathrm{P}$-value $=0.2)$ for Arsenic between the Chaney-Mielke and hot concentrated $\mathrm{HNO}_{3}$ method was insignificant.

- NIST Buffalo River Sediment was prepared and analyzed with the Chaney-Mielke extraction method and recovery rates were as follows: $\sim 100 \% \mathrm{~Pb}, \sim 80 \%$ As and $\mathrm{Cd}$, $\sim 50 \% \mathrm{Zn}$ and $\mathrm{Mn}, \sim 48 \% \mathrm{Cu}, \sim 32 \% \mathrm{Co}, \sim 20 \mathrm{Cr}$ and $\mathrm{Ni}, \sim 3 \% \mathrm{~V}$, and $130 \% \mathrm{Fe}$. These results provide a benchmark for the recovery efficiency of the Chaney-Mielke method of extraction.

- Given the strong associations between the microwave and Chaney-Mielke methods for most metals, it is possible to use an equation to predict the microwave totals for most of 
the metals from the results of the Chaney-Mielke extractions. This idea is being evaluated through further testing.

- The benchmark for determining the rate and degree of progress was the Analytical Products Group, Inc (APG) laboratory proficiency environmental testing program. Initially laboratory results were not at the necessary level of proficiency. Therefore, additional training and QA/QC procedures were implemented. The result was an improvement in proficiency from an average of less than 50 percentile (14 elements at one level of detection) to 72 percentile (11 elements at two levels of detection) in the last round. The Xavier laboratory ranked number one of 104 laboratories for percent acceptable data.

- The Perkin Elmer AA Graphite Furnace was installed and set for operations. This instrument provides the capability of measuring water samples and tissue samples with sensitivity that was not previously possible.

- Due to a proficiency test failure, it was discovered that the laboratory had a Zinc contamination problem. The probable source is the Zinc from tire wear on the I-10 highway adjacent to Xavier. It is estimated that $401.5 \mathrm{~kg}$ of Zinc per year are being emitted into the air through tire wear within the vicinity of the laboratory. Special efforts were taken to clean up all materials (plasticware, gloves, floors and tabletops) that come into contact with the standards and samples. Doing this markedly improved this laboratory's proficiency test results. Recognizing the potential for Zinc contamination, the same evaluation was applied to other laboratories in the building.

- Prepared and analyzed all available samples for Tunica Swamp and Devils Swamp soils and sediments using the $\mathrm{HNO}_{3}$ Chaney-Mielke method, or 400 samples.

- Tunica Swamp and Devils Swamp soil and sediment samples were prepared by microwave with concentrated $\mathrm{HNO}_{3}$ and 60 PSI. Approximately 50 samples were analyzed.

- Inter-laboratory comparison was conducted on 16 samples in conjunction with CIF. About 30 samples were analyzed.

- Analyzed Dr. Bhattacharya's bioreactor samples. Approximately 100 samples were prepared and analyzed.

- Prepared and analyzed Dr. Effiong's hexadecane/water emulsion samples. Approximately 20 samples were analyzed to support that project.

- During this quarter, approximately 670 individual analyses (including replications and blanks) were conducted to support the research for this grant. 


\title{
Analysis of Heat-Shock Protein Genes in Heavy Metal Contaminated Plant Species - Saururus (Lizard's-tail)
}

\author{
L. Thien, E. Ellgaard, D. Hurley, and D. Jobes
}

\section{Objectives and Goals:}

The objective of this project is to conduct preliminary investigations into the use of Saururus cernuus $L$. (Lizard's tail), a herbaceous plant with extensive rhizomes, in bioremediation. The study involves documenting the uptake of heavy metals by the plant and the location of the metals in various plant organs plus isolating genes (HSP 70; etc.) involved in heavy metal resistance.

\section{Accomplishments This Quarter:}

- Heavy metals in soils (spoil banks) along Bayou Trepagnier have been quantified and mRNA was isolated from plants exposed to heavy metals. The isolation of mRNA is an attempt to isolated specific genes. 


\section{COORDINATED INSTRUMENTATION FACLITY}

\section{Coordinated Instrumentation Facility}

T. Lyttle, D. Grimm, P. Burnside, W. Douglas, L. Smith III

\section{Objectives and Goals:}

The Coordinated Instrumentation Facility (CIF) provides analytical services and equipment maintenance and repair to the researchers involved in the grant. The CIF provides access to and support for state-of-the-art research instrumentation including equipment for analysis of trace metals and organic compounds. The CIF also provides electronics maintenance and repair for equipment used for research. All of these services are available to Tulane and Xavier researchers.

\section{Accomplishments This Quarter:}

- Inorganic laboratory successfully completed and passed APG PET for Arsenic, Cadmium, Chromium, Cobalt, Copper, Lead, Nickel, and Zinc.

- Inorganic laboratory used the ICP-AES and AAS to analyze fish, soil, sediments and water for metals and used the ED-XRF to analyze tree cores, soils and sediments for metals for this grant's projects.

- Organic laboratory performed fish, soil, sediment and water analysis for semivolatiles using the GC/MS.

- Summary of instrumentation time used for support of this grant for this quarter.

- ICP - AES -- 818 analyses for 718 samples using 184 hrs. of instrument time.

- GFAAS -- 3629 analyses for 1351 samples using $327 \mathrm{hrs.} \mathrm{of} \mathrm{instrument} \mathrm{time.}$

- XRF -- 1549 analyses for 1362 samples using $487 \mathrm{hrs}$. of instrument time.

- XRD -- 82 samples using 43.5 hrs. of instrument time.

- $\mathrm{GC} / \mathrm{MS}$-- 239 analyses for 16 samples and method development using 96.5 hrs. of instrument time.

- Organic laboratory performed Soxhlet extraction on $>20$ fish.

- Organic laboratory continues to develop dual column ECD method for detection of HCB and HCBD. 
- Electronics Shop provided support to several researchers for instrument repair including electronics support and applications training for Dr. Abdelghani's ICP.

- CIF hosted a one day workshop on ICP-AES and GFAAS presented by Perkin Elmer on Aug. 22. Complimentary registrations were provided to researchers performing trace metal analysis on this grant. A total of 60 people from the greater New Orleans area attended.

- Eight undergraduate students were hired to work in the CIF laboratories. Many of them are helping with sample preparation and documentation for analyses for this grant. 
Appendix A 
Summary of

Hazardous Materials in Aquatic Environments of the Mississippi River Basin Project Retreat

\section{June 19-20, 1995}


Retreat for the Tulane and Xavier Investigators

of the

'Hazardous Materials in Aquatic Environments in the Mississippi River Basin' Project

The Department of Energy (DOE) and

Tulane/Xavier Center for Bioenvironmental Research (CBR)

New Orleans Hyatt Hotel

June 19 and 20, 1995

The following is a summary of the Tulane and Xavier Universities DOE-EM Retreat presentations held at the New Orleans Hyatt Hotel on June 19 and 20, 1995:

I. Bayou Trepagnier: Leonard Thien, Ph. D., Cell and Molecular Biology, TU, Janet Preslan, M.S., Pharmacology, TUMC

George Flowers, Ph. D., Geology, TU

II. Devil's Swamp: William Hartley, Ph. D., Environmental Health Science, TUMC

III. Summary of Study Groups Regarding Future Research in the Project

\section{Bayou Trepagnier}

Presentation By: Leonard Thien, Ph. D.

Department of Cell and Molecular Biology

Tulane University

History of Bayou Trepagnier

The Norco Oil Refinery began modern operations in 1929-30. By-products of refining were dumped into Bayou Trepagnier. In 1950, the bayou was dredged. Spoil from dredging was placed on spoil banks on either side of the bayou. This process released contaminants that were bound in the sediments. In 1971, the bayou was designated a National Scenic River and, in 1972, was protected under the Clean Water Act. In 1985, the Department of Environmental Quality (DEQ), for the State of Louisiana, designated the bayou as contaminated and a threat to human health.

Shell Oil Company began studying the area in 1989. These studies culminated in 1995 in Shell's stopping the flow of cooling water from the Norco plant into the bayou. The bayou now stands as an embayment of Lake Pontchartrain. A 'borrow' area next to the lake has been dredged, and the spoils placed in a small lake next to the bayou.

At this point, Cypress trees remain the only 'old' vegetation left in the bayou. These trees have been exploited through tree core methods to reveal the history of heavy metals release in the area. Erosion caused by flooding in the area removes contaminants from the spoil banks and deposits them into the surrounding bayou and surrounding ecosystem. 
During the 'Big Flood of 1995', the water levels in the bayou rose 8-10 feet above normal. Occasionally, when the Bonne Carre Spillway is opened, water from the Mississippi River also influences pollution levels in the bayou. For the most part, water in the bayou ranges from 1-2 meters in depth. A paddle inserted into the mud releases heavy hydrocarbon odors.

Still, wildlife such as eagles, rare plants, rushes and palms, are still found in the bayou. Duck, deer, and alligator hunting are still pursued in the bayou as well as fishing, canoeing and bird watching. An archeologic site, a very large shell midden, remains at the bayou. Still, their are plans to alter the bayou again. One oil company wants to dump waste into Bayou La Branche, which is the adjacent bayou. Other plans are to place extensions of the current airport in the bayou area. An active 'save-the-wetlands' group opposes these changes.

Presentation By: Janet Preslan, M.S.

Department of Pharmacology

Tulane University School of Medicine

The summary of the status of Bayou Trepagnier represents work of many members of the Tulane/Xavier researchers and other DOE/EM investigators including Drs. Anderson, George, McPherson, Flowers, Means, Maskarinec, Suhayda (LSU), Fingerman and others.

Bayou Trepagnier is a 3.5 mile long waterway in the La Branche wetlands adjacent to the Bonnet Carre Spillway structure connecting the Mississippi River and Lake Pontchartrain. Sediments in the bayou are contaminated with petroleum products, particularly at the southern, upstream portion of the bayou near the refinery complex. Surface sediments at the most heavily contaminated sites are of low density and are fluid, with solids representing only $20 \%$ of the total weight of the sediment (post drying at $105 \mathrm{Deg} \mathrm{C}$ ). Little humus-like material is present in comparison to the sediments found in neighboring bayous. Deeper sediments consist of dense clay. Polyaromatic hydrocarbons including benzo(g,h,i)perylene, chrysene, naphthalenes, and benzo(b)fluoranthene have been identified, with total PAH levels as high as $50 \mathrm{mcg} / \mathrm{gm}$ sediment. A broad spectrum of branched and chain aliphatic hydrocarbons as well as elemental sulfur are also present. Zinc $(2000 \mathrm{ppm})$, lead $(1500 \mathrm{ppm})$ and chromium $(1300 \mathrm{ppm})$ are the most abundant metal contaminants in surface sediments. Volatile organics (1,1 dichloroethene, 2-butanone, 1,2dichloropropane, 1,1,2-trichloroethane, chlorobenzene, xylene, and 1,1,2,2tetrachloroethane) have been measured in the sediments with levels of individual compounds as high as $1090 \mathrm{ng} / \mathrm{gm}$ where contamination is the highest.

The concentration of contaminants in the sediments increase with depth. Oil and grease levels determined from $25 \mathrm{~cm}$ long sediment cores show highest levels of $17,000 \mathrm{mg} / \mathrm{kg}$ $(1.7 \%)$ at the $25 \mathrm{~cm}$ depth. Highest levels of metals contamination have been reported at 35 to $75 \mathrm{~cm}$ depths (zinc $2500 \mathrm{ppm}$, lead $7000 \mathrm{ppm}$, and chromium $5000 \mathrm{ppm}$ ) by La DEQ in 1989. 
Tide, wind and rainwater run-off from the surrounding wetlands are the primary factors influencing the water levels in Bayou Trepagnier. The effect of wind velocity and direction has a particularly strong effect since the mean water depth of the Bayou is only 3 to 4 feet. Lake Pontchartrain water is driven into Bayou Trepagnier by a northerly wind, and Bayou water is emptied into the Lake by a southerly wind. Fluctuations of over 14 inches in water depth have been observed under fair weather conditions. An additional hydrologic influence beginning in 1966 was the Shell Manufacturing Complex (SMC) discharge of stormwater runoff as well as waters used for coolant in its plant operations into the southern headwaters of Bayou Trepagnier. The discharge was variously described as 15 million gallons per day, or 0 to 15,000 gallons per minute ( 0 to 33 cubic feet/second). Although hydrologic studies sponsored by Shell describe the effluent as being only a small percentage of the total water budget of the Bayou, the effluent represented net downstream flowing water which exerted a flushing effect (as opposed to balanced tidal inflow and outflow) especially in periods of low rainfall. This source of water was diverted away from Bayou Trepagnier and into the Mississippi River in February, 1995.

Water levels with Bayou Trepagnier have not been altered by the lack of SMC inflow. The biomass of floating aquatic plants has dramatically increased, however. Bayou Trepagnier has changed from a waterway with a scarcity of aquatic plants to one where the surface is thickly carpeted with Lemna and where water hyacinth have appeared for the first time since the initiation of the study.

A sewerage treatment plant for the town of Norco discharges on average $0.5-0.8$ million gallons per day of treated (chlorinated) wastes into the headwaters of Engineers Canal which exchanges water with Bayou Trepagnier through the cross channel at Marker 58. The levels of nutrients present in Bayou Trepagnier since February, 1994, have fluctuated over a wide range and were generally higher than in neighboring Bayou Traverse of Lake Pontchartrain. Highest levels observed were during a low water period in March of 1994. The relatively large proportion of nitrogen $(N)$ as toxic nitrites and as ammonia in Bayou Trepagnier reflect the presence of ecologically less desirable reducing conditions.

$\begin{array}{llc}\text { Nutrients } & \text { B. Trepagnier } & \text { L. Pontchartrain \& B. Traverse } \\ \text { N-Nitrates } & 515 \mathrm{ug} / \mathrm{L} & 199 \mathrm{ug} / \mathrm{L} \\ \text { N-Nitrities } & 1317 \mathrm{ug} / \mathrm{L} & 16 \mathrm{ug} / \mathrm{L} \\ \text { N-Ammonia } & 1733 \mathrm{ug} / \mathrm{L} & 102 \mathrm{ug} / \mathrm{L} \\ \text { P-Phosphates } & 1083 \mathrm{ug} / \mathrm{L} & 174 \mathrm{ug} / \mathrm{L}\end{array}$

By contrast, the most uniform nutrient levels throughout the waterways of these wetlands was seen just one year later, March, 1995, during a period of extended heavy rains. Distribution of nitrogen-base nutrients reflect a much more favorable oxidizing conditions.
Nutrients
N-Nitrates
B. Trepagnier
N-Nitrities $327 \mathrm{ug} / \mathrm{L}$ $9 \mathrm{ug} / \mathrm{L}$
L. Pontchartrain \& B. Traverse $315 \mathrm{ug} / \mathrm{L}$ $3 \mathrm{ug} / \mathrm{L}$


The acidity of all the LaBranche waterways has increased between March, 1994 and April,

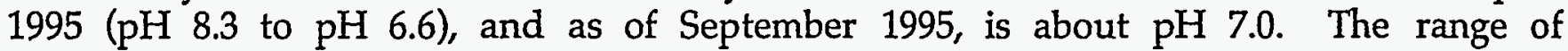
conductivity observed was 4.23 to $0.42 \mathrm{mS}$, with fluctuations occurring fairly simultaneously throughout all waterways in these wetlands. Dissolved oxygen levels, as measured from 9 am to $12: 30$ noon, ranged from greater than $8 \mathrm{mg} / \mathrm{L}$ in the colder winter months to less than $1 \mathrm{mg} / \mathrm{L}$ in the summer heat, a stressfully low level to aquatic organisms. Lowest oxygen levels are frequently seen in the contaminated southern most area of Bayou Trepagnier. Alkalinity of the water throughout the wetlands ranged from 20-190 ppm calcium carbonate, with Bayou Trepagnier averaging about $50 \mathrm{ppm}$ higher than Bayou Traverse and the Lake.

Fish populations are less diverse (primarily alligator gar) in the contaminated upper Bayou than in the portions of the Bayou nearer the Lake or in neighboring waterways within the same wetlands region. Tubificid worms were evident in sediment cores collected in 1994, but not in 1995. Native crayfish occur the northern region of the Bayou, but are scarce upstream. In a field exposure study, commercially-reared crayfish introduced via cages into a heavily contaminated Bayou Trepagnier site, accumulated measurable lead and chromium in a period of only 7 days. Changes in the enzyme systems of the exposed animals have been observed.

Studies were conducted in the Bayou in May, 1994, during an experimental opening of the Bonnet Carre Spillway by the Army Corps of Engineers (COE) and the U.S. Geological Survey (USGS). During the 11 days that the Spillway was open, 23,000 million cubic feet (MCF) of Mississippi River water (a quantity equal to $12 \%$ of the volume of the Lake), was discharged into the Lake Pontchartrain at location about 3 miles from the confluence of the LaBranche and the Lake. Winds were initially from the southeast, then shifted to the south during the course of the study, and the results of tracking the movement of a tracerdye in the River water (USGS) documented that the movement of River water was indeed in a direction away from the LaBranche wetlands during the study. Changes in the water levels in the Bayous Traverse and Trepagnier correlate to the wind shift rather than to the rate of discharge of the River into the Lake. Nutrient levels in the bayous were not notably altered. By the time the Spillway was closed, an uncharacteristic, light-colored sediment covered the Bayou bed in the northern (Lake) end of Bayou Trepagnier. As a result of the Spillway Experiment, COE is considering the possibility of diverting the Mississippi River water into the LaBranche wetlands, allowing it to drain though the marsh prior to entering the Lake.

In summary, Bayou Trepagnier is a shallow waterway with bed sediments, particularly at the southern upstream end, contaminated by petroleum products including polyaromatic and aliphatic hydrocarbons, volatile organics, oil and grease, zinc, lead, chromium, and sulfur. Possible evidence of a negative impact of contaminants include reduced species diversity of fish, reduced numbers of crayfish and benthic worms, and preliminary 
investigations which indicate that at least some of these contaminants are bioavailable and damaging to aquatic life. Sewerage discharged into the headwaters is apparently the source of elevated nutrient levels in the Bayou. Since the divergence of rainwater runoff from the surrounding watershed, and Lake Pontchartrain water introduced by tide or wind. Water levels have not fallen since the divergence of SMC water, but biomass of floating plants has increased. The $\mathrm{COE}$ is presently considering the possibility of diverting Mississippi River water into the wetlands adjacent to the Bayou.

In attempts to analyze the food chain in the bayou, an alligator gar, caught in the bayou, was found to have a whole nutria in its stomach. In addition, big owls and eagles are present, preying on other mammals found in the bayou.

More alligators have been sighted this year after Shell turned off the water flow from the plant. Water in the bayou contains floating mud balls which are composed of plant roots and mud. Mud is contaminated because contaminants are bound to sediment. Plants can withdraw contaminants from the mud and reintroduce them into the water through their metabolism.

Halfway up the bayou, the bottom sediments are so contaminated that they are actually 'pourable'. Oil can be seen floating at the edges of the bayou near the banks. Higher up in the bayou, frogs can be found in 'pot-holes'. The nutrient levels in the bayou have been decreasing in recent months, probably due to flooding and to the shut-off of water from the Shell plant.

Presentation By: George Flowers, Ph. D.

Department of Geology

Tulane University

The effluent cooling water that Shell was emptying into the bayou had to meet clean water standards set by the Environmental Protection Agency (EPA). Since it didn't, it was ordered by EPA to divert the discharge to the Mississippi River instead of the bayou. This water also contains storm water in addition to cooling water.

In Bayou Trepagnier, the spoil banks are 5 feet in height along the bayou. Shell has placed markers every 100 feet. The water in Bayou Trepagnier communicates with water that comes from an adjacent engineering canal and also from water from the La Branche wetlands. There is continual input into the bayou from rain water at the headwaters. There is also input from wind, which fills and drains the bayou from the lake. A pronounced lead spike occurs in water samples taken at Site \#60. Chromium is high at the headwaters and also at Site \#60 in the sediments. Copper is not enriched much in the sediments. Zinc is high in headwater sediments.

The water quality, for example, the $\mathrm{pH}$, regulates dissolved metals and also their toxicity. The metals tend to stay in the spoil banks and do not enter the water, however, the metals can complex with acid volatile sulfides, that is, metals binding with iron sulfide found in the sediments to produce metal sulfides plus iron. The fact that low metals are found in 
the water is compatible with the acid volatile sulfide hypothesis, that is, that the metals remain bound to these sulfides in the sediments. In the water, hardness, that is, the amount of minerals dissolved in the water changes with wind and water movements.

\section{Devil's Swamp}

Presentation By: William Hartley, Ph. D.

Department of Environmental Health Sciences

Tulane University Medical School

There are two sources of pollutants entering Devil's Swamp. One from what is referred to as the 'scenic highway' site and the other being the 'petro processor' site or also referred to as the 'Brooklawn' site. These areas were declared a Superfund site in 1984, although the Devil's Swamp itself is not part of the Superfund site. The hydrocarbons hexachlorobenzene ( $\mathrm{HCB})$ and hexachlorobutadiene ( $\mathrm{HCBD}$ ) are present at these sites.

In 1959, 'fill' was removed from the 'scenic highway' site to make a highway. It produced a 20 foot deep pit: six acres in size. In 1964, the Petroprocessors, Inc., buried 60,000 tons of waste at this pit site. Wastes included $\mathrm{HCB}, \mathrm{HCBD}$ and other chlorinated solvents and organics. Since then, there has been 10 years of health advisories about fish caught near the site.

In 1969, the levy around the 'Brooklawn' site broke. Cattle and wildlife in the area died as a result of the release of contamination. In 1974, a permit was issued to bury solid waste at the site. By 1979, the permit was revoked. In 1980, no materials were received at the plant. In 1984, a major fire broke out at the 'Brooklawn' site. That same year it was declared a Superfund site. In 1986, the state tried to add the Devil's Swamp as part of the Superfund site, but the EPA denied the request. Also in 1986, an eco-risk assessment was done by NPC.

In 1993 the Department of Environmental Quality (DEQ) and Office of Public Health (OPH) of Louisiana issued a health advisory for Bayou Baton Rouge and Devil's Swamp. The advisory stated that "...no more than two meals of fish per month should be eaten due to the presence of HCB and HCBD 'carcinogens' in the fish..." Also, a skin contact advisory, due to arsenic in the water, was issued and swimming was banned.

The swamp itself is a typical Mississippi River flood plain, that is, at low river stages water flows from Bayou Baton Rouge to the Devil's Swamp and then to Devil's Swamp lake and then ultimately to Baton Rouge Harbor. At high water stages, the water backs up through the swamp. Devil's Swamp lake was dug for 'fill' to make levies. The Tunica Swamp, found upstream, serves as a control swamp. Comparing fish from Devil's swamp and Tunica Swamp reveals equivalent diversity. Critical results include the identification of histopathological biomarkers in channel catfish (Ictalalarus panclalas), yellow bullhead (Ameiurus natalis), black bullhead (Ameirus melas), spotted gar (lepisosteus oculatus), smallmouth buffalo (Ictiobus bubalus), and bigmouth buffalo (Ictiobus cyprinellus) . 
Most fish species from Devil's Swamp bioaccumulated HCB, HCBD, mercury, and other metals. In general, the concentration of chemicals increased in muscle tissue with increasing fish length. Increased levels of hepatocellular iron and melanomacrophage center (MMC) iron, and larger MMC were noted in the liver of gar from Devil's swamp with significant body burden of HCB, HCBD, mercury, and other metals. In general, the concentration of chemicals increased in muscle tissue with increasing fish length. Increased levels of hepatocellular iron and melanomacrophage center (MMC) iron, and larger MMC were noted in the liver of gar from Devil's Swamp with significant body burden of HCB, HCBD, and heavy metals. Smallmouth buffalo from Devil's Swamp accumulated metals in muscle tissue and had a higher prevalence of variety of gill lesions than fish collected from the control site, Tunica Swamp. We are in the process of further quantification of these and other biomarkers of exposure to a mixture of chemicals typical of Devil's swamp. Fish population dynamics are also being coordinated with the biomarker studies for a comprehensive model of sentinel fish species.

\section{Highlights of Study Groups Regarding Future Research in the Project}

\section{Analysis Cluster}

Both the historical records for Bayou Trepagnier and Devil's Swamp, as well as current studies, show that both areas are very definitely still polluted with hydrocarbons and heavy metal contaminants. The Analysis supercluster regards its capabilities at measuring heavy metals as being appropriate at this point, however, hydrocarbon analysis remains focused on measuring semi-volatile hydrocarbons.

At some point, the ability to measure volatile hydrocarbons should be added. In addition, labs that are part of this analysis supercluster must standardize their data. These data must be meaningfully compared between analysis labs and must be entered in one format in the Geographic Information System (GIS) data base.

\section{Biomarker Cluster}

The Biomarker supercluster noted that common biomarkers of interest have emerged in both field studies and lab studies. In addition, field placement of organisms normally studied in the lab has become a reality. That is, for example, crayfish placed in Bayou Trepagnier show detrimental effects similar to those produced by exposure in the laboratory to contaminants found in Bayou Trepagnier. This approach will be continued with a variety of organisms.

\section{Ecology Cluster}

The Ecology cluster will begin moving its approach to that of studying the whole ecosystem. Areas around the bayou will also be studied to understand how the pollution in the bayou influences joining ecosystems and how these systems influence polluted areas in the Bayou.

Fate and Transport Cluster 
Continual efforts are being made to interface computational models with 'real-world' behavior of micro-organisms and particles.

\section{Remediation Cluster}

The Remediation cluster is set to move from background work to begin real treatment of site derived contaminants.

\section{Summary}

In summary, individual clusters have evolved to become Super-clusters related to core themes. For example, the Analysis cluster, the Biomarkers cluster and Ecology cluster are now working in an integrated fashion. Very shortly, with the help of GIS analysis, the Remediation and Fate and Transport clusters will begin interfacing with the Biomarker/Ecology/Analysis Super-cluster.

Integration of all data in this manner will provide insight concerning the scope of natural cleansing processes in the two study sites, and will provide solid data for charting ecosystems health related to pollution discharge by energy production activities. 
Retreat for the Tulane and Xavier Investigators

of the

'Hazardous Materials in Aquatic Environments in the Mississippi River Basin' Project

The Department of Energy (DOE) and

Tulane/Xavier Center for Bioenvironmental Research (CBR)

New Orleans Hyatt Hotel

June 19 and 20, 1995

The following is a summary of the Tulane and Xavier Universities DOE-EM Retreat presentations held at the New Orleans Hyatt Hotel on June 19 and 20, 1995:

Expert Geographical Information Systems for

Assessing Hazardous Wastes in Aquatic Environments

\section{FATE, TRANSPORT AND MODELING GROUP}

Panelists:

Dr. Reda Bakeer, Department of Civil Engineering, Tulane

Dr. Elia Eschenazi, Department of Physics, Xavier

Dr. Lisa Fauci, Department of Mathematics, Tulane

Dr. William Toscano, Department of Environmental Health Science, TUMC

I. Progress to Date

- Setting up two GIS systems and developing a third at Xavier University

- Hire two positions for the project

- Increase cluster involvement and communication by creating a GIS subgroup consisting of one person from each project. This person will serve as the contact for their project, exchange information with GIS personnel and attend the subgroup meetings.

- Implement GIS workshops for DOE/EM participants to learn more about the GIS systems and its capabilities.

- Continue to create and maintain a vast project wide data base.

II. Goals

- Produce maps reflecting DOE/EM data.

- Examine cumulative data and relational information including ecological \& health risk assessment.

- Obtain fiber optics communications between schools.

- Freeport McMoRan - river study.

\section{Future Funding}


- Industrial projects (Freeport-McMoRan)

- Stay in line with the national goals of Major GIS systems

Collaborative Research With the Institute of Radiological Problems in Minsk: Mathematical Modeling and Computer Simulations on the Fate and Transport of Radionuclides in Belarus Following the Chernobyl Accident.

- Studying the transport and fate of radionuclides and their redistribution. Flocculation and Interfacial Tension Studies in Environmental Processes

- Setting up light scattering experiments to study particle size distributions and flocculation kinetics.

- Doing 2 and 3 dimensional Monte Carlo simulation for collisional probabilities in concentrated emulsions.

Pore-Level Flow, Transport, Agglomeration and Reaction Kinetics of Microorganisms

- Coordinating experimental and computational bacteria motility in micro pores in the presence of a dissolved substrate.

- Studying the formation of biofilms.

Biotic and Abiotic Studies on the Biological Fate, Transport and Ecotoxicity of Toxic and Hazardous Waste in the Mississippi River Basin.

- Analyzing sediments in Devil's Swamp to understand the toxicants and investigating their diffusion.

- Recreating field environments in the lab using tanks with 12 in. of sediment.

Goals for Modeling/Fate and Transport Groups

- Coordinate meetings with other modeling groups to share information and increase communication.

- Work closely with GIS to increase scope of capabilities and share information.

- Using modeling to incorporate new fate and transport data.

\section{Future Funding}

- Industrial contacts

- Biofilm studies

- NSF software development in computational biology and geophysics

\section{Summary}

Contaminants enter the bayous and diffuse, but in certain cases, are held in place. The movements of contaminants are influenced by the geometry of the system and by the connectivity, within the system, of different environmental phases as well as connectivity to surrounding areas. In addition, the contaminants are changed by the biology of the system where contaminants can be made unavailable by the activities 
of micro-organisms, for example, plants. To truly model fate and transport in, for example, Bayou Trepagnier, it is necessary to know both the 'field scale', which occurs over miles, and also the smaller scale, for example, how coupled process' work at a micro-scale, down to the molecular scale. These issues can be studied not only in the environments at hand, for example, Bayou Trepagnier, but also in another sub-project in Belarus. This project focuses on the fate and transport of radionuclides from the Chernobyl site. Studies include mathematical modeling and also lab studies that chart how metals move between environmental phases. The goal is to coordinate both lab and computational models of fate and transport and to understand how, for example, bacterial movements are limited by pore geometry, and, how computational models can be used to predict the pollutant bacterial interactions. In all cases, the projects must tie modeling, ultimately, to real work in the field.

\section{BIOMARKERS CLUSTER}

Panelists:

Dr. William Hartley, Environmental Health Sciences, TUMC

Dr. Milton Fingerman, EEO Biology, Tulane

Dr. Patience Obih, Pharmacy, Xavier

Dr. Krishna Agrawal (for Dr. Mary Anderson), Pharmacology, TUMC

\section{Progress to Date}

- Acetylcholinesterase (AChE) activity: crayfish, fish and frogs, activity decreased upon exposure.

- To correlate specific site conditions, including levels of contaminants in the sediment, water and crayfish with $\mathrm{AChE}$ activity.

- To conduct experiments with site contaminants in fish and frogs in laboratory studies.

\section{METALLOTHEIONIN}

- Induction can serve as a biomarker

- PCR

- ELISA ASSAY has been developed with catfish; will extend study to crayfish.

INTERLEUKIN 1-ß

- frogs (brain and spleen tissues)

- use of cDNA probes for measuring alternations in gene expression

- changes in cytokines vs. exposure using ELISA

- changes in cytokines vs. development

SUPEROXIDEDISMUTASE (SOD)

- absent in crayfish

- whether chromium affects SOD activity is being studied 


\section{INCREASE IN DNA PLOIDY}

- seen in spermatozoa of crayfish after exposure to metals HYPERGLYCEMIA

- occurs in crayfish with cadmium exposure MICROINJECTION OF HCB

- development (heart development)

- looks for chronic effects

- do embryo microinjection

- this method allows precise dosage of mixtures HISTOPATHOLOGICAL BIOMARKERS

- mmc (melanin macrophage centers) positively correlate with mixed pollution (fish)

- other markers are being developed in small and large mouth

II. Goals buffalo and species of gar.

- Field studies with all of the above biomarkers: fish, frogs, and crayfish will be kept in cages. If any or all biomarkers in the field are change with exposure to contaminants, then,

- Lab studies to identify the chemical contributor(s) (cause and effect) will be done.

- Additional histochemistry:

EM for mmc studies

Pan mono marker for mmc studies

EDAX Scanning (SEM) and Transmission (TEM) Electron Microscopy for metals in specific cell types will be attempted.

- Devise a laboratory model for mmc studies

- Working hypothesis: biomarker responses are related to contaminant levels.

\section{Future Funding}

Prediction of Biomarker Expression in Additional Exposed Ecosystems

- sample additional sites (and/or GIS data base) and use contaminant data to predict patterns of biomarker expression in fish, crayfish, and frogs.

Reproductive Pathology

- Hermaphroditism

- Testes and Ovaries (including morphological variations)

Fertility Studies

- Histopathology

- DNA-flow cytometry

- Sperm biology micro-manipulation technology

- Developmental 
- Mutational studies - embryological development

- Hormonal mechanisms

Devil's Swamp and Tunica Swamps

- evaluation of gonads for abnormalities and identification of sentinel species. Laboratory studies to follow based on field results.

\section{Summary}

Highlights of the Biomarkers cluster include showing dramatic changes in crayfish placed in cages in Bayou Trepagnier with regard to functions in ovarian tissues and gastric tissues. In addition, in laboratory studies with crayfish, it was shown that naphthalene damages the crayfish hepatopancreas, but when exposure was terminated, the hepatopancreas was shown to regenerate.

Future studies will include fish, frogs and crayfish neuroendocrine mechanisms that influence both development and fertility. Additionally, a lab ecosystem will be set-up to use duckweed, which concentrates contaminants such as HCB and HCBD, in a food chain study to determine the effects of feeding contaminated duckweed to crayfish with regard to the biomarkers already described. Lab studies will also model in situ effects in the three category organisms. An effort will be made to better correlate lab and field studies, and to begin using GIS base data to predict exposure levels at specific sites.

\section{ANALYSIS CLUSTER}

\section{Panelists:}

Dr. Assaf Abdelghani, Environmental Health Sciences, TUMC

Dr. Mary Anderson, Anatomy, TUMC

Dr. Debby Grimm, Coordinated Instrumentation Facility, Tulane

Dr. Gary McPherson, Chemistry, Tulane

Dr. Howard Mielke, Pharmacy, Xavier University

I. Progress To Date

- Equipment Acquired

$\begin{array}{ll}\text { CIF } & \text { ICP Spectro with Ultrasonic Nebulizer } \\ & \text { Graphite Furnace AA } \\ & \text { Microwave digester } \\ & \text { XRF } \\ & \text { Microwave asher } \\ & \text { Sample prep equipment } \\ & \text { GC Upgrade } \\ & \\ \text { SPHTM } & \text { Ultrasonic Nebulizer } \\ & \text { Microwave digester } \\ & \text { Microwave asher } \\ & \text { Supercritical Fluid Extractor }\end{array}$


Clean room environment

Graphite furnace AA

Microwave digester

Supercritical Fluid Extractor

TUMC Microwave digester

AA upgrade

- Expanded capabilities by hiring additional analytical staff.

APG inorganic proficiency test at 4 labs:

initially lead only

as of $1 / 95 \mathrm{As}, \mathrm{Pb}, \mathrm{Cr}, \mathrm{Cu}, \mathrm{Cd}$

Common Samples between labs sediments \& soils with different values reported sampling + sample prep related.

Determined that Bayou Trepagnier filtered water samples show low lead; however, the sediments clearly have elevated levels of heavy metals, lead in particular.

There is little evidence to date that lead has migrated out of Bayou Trepagnier, but there is evidence of lead accumulation in cypress trees at Bayou Trepagnier.

A quarterly sampling schedule has been established for Devil's Swamp . Routine inorganic analyses of Devil's Swamp and Tunica Swamp sediment samples are being conducted. The trends remain consistant. Tunica Swamp exceeds Devil's Swamp samples with respect to most metals analyzed.

Identified $\mathrm{AS}, \mathrm{HCB}$ and $\mathrm{HCBD}$ as contaminants of concern at Devil's Swamp.

Arsenic levels in edible portions of fish samples from Devil's Swamp may pose human risk in edibles.

Bioaccumulation for some samples from Devil's Swamp have been established. Comparisons with Tunica Swamp are under way. 
II. Goals

Current Year:

Establish internally spiked samples. Exchange among labs.

Create a contaminated sample reference soil and sediment to be run with each batch.

Regular meetings (quarterly) of lab managers in conjunction with QA/QC meeting.

Have a meeting of the labs to determine equipment needs for the next two years.

Look into performance based analytical methods to replace specified analytical protocol based methods.

$\underline{1996}$

Acquire additional equipment needed for organic analysis.

GC Mass Spec

Microwave Extractor for organics

LIMS

Focus chemical analysis to fit biology studies.

Continue analytical services by upgrades and maintenance.

$\underline{1997}$

Continue analytical services by upgrades and maintenance.

III. Future Funding - Potential Hypotheses for Future Funding

Establish, by site characterization, a laboratory in the field that can be used by multi-disciplinary teams to evaluate remediation technologies.

Establishment of a proven cost-effective laboratory system.

\section{Summary}

The Analysis cluster needs to consider including volatile hydrocarbons in their analysis. In addition, the group needs to develop standards, not only for testing the accuracy of their analysis equipment, but also for the accuracy of their extraction equipment. It was emphasized by DOE collaborators that the Analysis group cluster needs to standardize the presentation of their data. Ideally, the four labs involved would settle upon a common standard extraction procedure, for example, sediments and tissue samples and common proficiency tests for specific types of samples. Ultimately, normalized data should be provided for GIS analysis. 


\section{REMEDIATION}

\section{ECOLOGY}

It should be noted that a $30 \mathrm{~cm}$ core $(3 \mathrm{~cm}$ across) taken in sediments near the headwaters of Bayou Trepagnier, appears as a gooey mass which contains a broad spike of organics and sulfur. Hydrocarbons are also found in Killifish caught in this area. The $\mathrm{pH}$ in Bayou Trepagnier has changed throughout 1994-95. It is getting lower. This could be a function of the profound flooding in the area, in addition to the fact that Shell stopped emptying water into Bayou Trepagnier. There has also been a decrease in ammonia, nitrates, oxygen and the number of worms found in the sediments. The tree-ring studies should include some older trees, and trees should be sampled that are away from the spoil banks. In an approach to the ecosystem as a whole, it will be necessary to identify 'hot-spots' of contamination throughout the area. Attention should be paid to trees, fish, crayfish, and plants away from the contaminated streams. Models that are predictive need to account for whole eco-system effects.

\section{Biogeochemical Remediation of Hazrdous Wastes in Aquatic Environments Breakout Session Summary}

\section{Progress To Date}

Several promising technologies are currently under development for the remediation of hazardous wastes in the aquatic environment, including 1) novel membranes for the removal of dissolved organics and heavy metals from waste streams; 2) chemoenzymatic ocidation, polymerization, and subsequent removal of dissolved aromatic hydrocarbons; 3) bioremediation of organic substrates using sulfate reducing bacteria, methanogens, white rot fungi, and sulfide oxidizing bacteria; and 4) encapsulation of waste in crystalline solids, such as phosphate-based microporous solids (zeolites) and synthetic polysulfides.

\section{Goals for 1996-97}

Investigators working on remediation technologies plan to:

1. Develop cooperative ties with companies actively engaged in remediation of hazardous waste in aquatic environments in order to gauge the practical applicability of developing remediation technology.

2. Focus basic research and technology development on a specific set of compounds of interest to DOE.

3. Foster research ties between investigators working in chemical and biological remediation by seeking to develop novel treatment strategies that use chemical precooking of waste to enhance biodegradability. 
4. Explore the applicability of chemical treatment methods to remove soluble metabolic products that inhibit biotreatment or impact organisms in the ecosystem.

5. Test treatment methods in the laboratory using samples taken from the Devil's Swamp, Bayou Trepagnier, and other sites where targeted chemicals may pose a threat to the ecosystem.

\section{Hypothesis}

Novel remediation technologies currently under development will aid DOE in cleaning up toxic waste in aquatic environments adjacent to energy-related industrial facilites. Site-specific tests of this hypothesis should provide a means for garnering additional research support for the remediation clusters in the future.

\section{Additional Comments}

Remediation science is obviously a critical part in any attempt by DOE to deal with its hazardous waste problems. It is also important in developing fabrication processes that curtail or eliminate waste discharge into ecosystems, the so-called "green chemistry" approach.

Research focused on developing novel remediation technologies should not be restricted to Devil's Swamp or Bayou Trepagnier. We need the flexibility to test remediation techniques at sites where targeted chemicals are both a real concern and present in a phase appropriate to the remediation technology being tested. For example, the utility of a novel membrane designed to remove metals at the ppm level in waste streams could not be tested in Bayou Trepagnier where the dissolved metal content of the water is low.

\section{Bayou Trepagnier Summary \\ George C. Flowers}

Bottom sediments of Bayou Trepagnier are highly contaminated with $\mathrm{Pb}, \mathrm{Zn}$, and $\mathrm{Cr}$. The $\mathrm{Cu}$ content of bottom sediments is to a lesser degree enriched relative to the average shale. Contaminated sediments are also found in spoil banks mainly on the west side of the bayou. The distribution of heavy metals in bottom sediments is highly irregular, suggesting that the surface contamination is probably due to erosion and deposition of dredge spoil in the channel. Despite the occurrence of highly contaminated bottom sediments, sediment pore waters contain low concentrations of dessolved metals. Bottom sediments contain abundant acid volatile sulfide (AVS) which probably limit the dissolved $\mathrm{Pb}, \mathrm{Cu}$, and $\mathrm{Zn}$. In addition, the neutral $\mathrm{pH}$ of the bayou limits the solubility of metals, particularly $\mathrm{Pb}$. Elutriate and static dissolution tests indicate that metals are bound to bottom sediments and have limited potential for release into the water column. However, disruption of bottom sediments or erosion of spoil banks probably increases the suspended load and total metal content of the water column. As expected, the AVS content of spoil banks is low. Metals previously bound as stable sulfides may have contaminated surface runoff from the spoil banks. Metals introduced into the water column are associated with suspended particulate matter. Sediment samples taken 
in Lake Pontchartrain in the vicinity of Bayou Trepagnier are not contaminated with heavy metals. Preliminary data for lake sediments indicates that there is no contamination plume from Bayou Trepagnier. However, the lack of contaminated sediments does not preclude metal transport in the colloidal phase. 